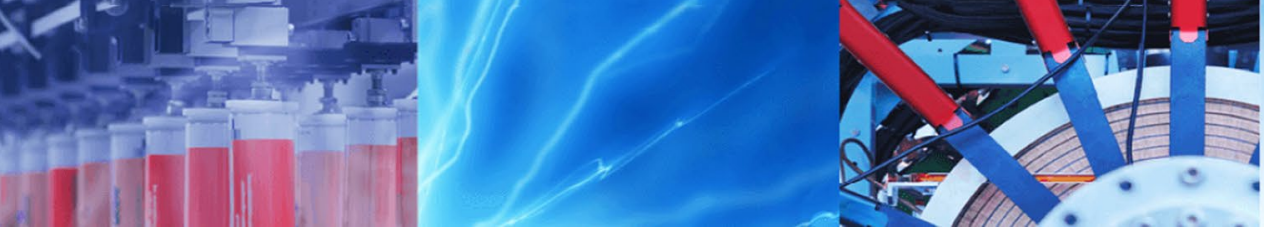

Research Article

\title{
Assessment of potentially harmful elements in floodplain soils and stream sediments in Ile-Ife area, South-western Nigeria
}

\author{
I. T. Asowata ${ }^{1} \cdot$ A. S. Akinwumiju²
}

Received: 22 April 2020 / Accepted: 30 July 2020 / Published online: 12 August 2020

(c) Springer Nature Switzerland AG 2020

\begin{abstract}
The enrichment of potentially harmful elements (PHEs) in stream sediments (SS) and floodplain soils (FS) poses great environmental hazards to water bodies and other parts of the ecosystem. The aim of this research was to evaluate the distribution pattern of selected PHEs ( $\mathrm{Cu}, \mathrm{Pb}, \mathrm{Zn}, \mathrm{Co}, \mathrm{Mn}, \mathrm{As}, \mathrm{Cd}, \mathrm{V}, \mathrm{Cr}, \mathrm{Ni}, \mathrm{Th}, \mathrm{Sr}$ and $\mathrm{La}$ ) in $\mathrm{SS}$ of selected rivers that drain Ile-Ife area and their adjacent FS, to ascertain the pollution status of these elements in the study area. Sixty samples (40 SS and 20 FS) were purposely collected for this study; the samples were analysed with ultra-trace inductively coupled plasma mass spectrometry method (ICP-MS). The PHEs results showed decreasing trend of average contents of PHEs studied; $\mathrm{Mn}>\mathrm{Zn}>\mathrm{V}>\mathrm{Cr}>\mathrm{Pb}>\mathrm{La}>\mathrm{Sr}>\mathrm{Cu}>\mathrm{Ni}>\mathrm{Co}>\mathrm{Th}>\mathrm{As}>\mathrm{Cd}$ for both $\mathrm{SS}$ and FS. Also, PHEs concentration in the studied geo media showed a significant level of enrichment as observed from the results. Elemental association showed positive correlation for topsoil, $\mathrm{Pb} / \mathrm{Zn}=R^{2}, 0.85$ and negative correlation for topsoil $\mathrm{Cr} / \mathrm{Zn}=R^{2} 0.02$ among the other PHEs. Source apportionment showed that the studied metal enrichment is largely anthropogenic rather than geogenic. Geoaccumulation and metal ratio indexes indicated that FS and SS studied have received significant PHEs of between moderately to strongly polluted, which implies significant environmental implications in the study area.
\end{abstract}

Keywords Potentially harmful elements · Ile-lfe · Enrichment · GIS · Aqua regia

\section{Introduction}

Stream sediments and floodplain soils are important part of the ecosystem that may serve as sink for pollutant such as potentially harmful elements (PHEs). According to [5], PHEs are described as group of metals and metalloids that are associated with pollution and toxicity. Of these PHEs, living organisms need some tolerable quantity (amounts), which are referred to as essential metals for body metabolisms and nutrients, $[16,35]$. These metals include $\mathrm{Co}, \mathrm{Cu}$, $\mathrm{Fe}, \mathrm{Mn}, \mathrm{Zn}$ among others, [5]. In some cases, they can alternately be referred to as trace elements, $[5,15]$. In this study, the PHEs that were determined include copper $(\mathrm{Cu})$, lead $(\mathrm{Pb})$, zinc $(\mathrm{Zn})$, nickel $(\mathrm{Ni})$, cobalt $(\mathrm{Co})$, manganese $(\mathrm{Mn})$, arsenic (As), thorium (Th), strontium (Sr), cadmium (Cd), vanadium (V), lanthanum (La) and chromium (Cr). These pollutants can reach an enrichment level that may pose serious environmental health risk to man and the biota $[32,45]$. Due to expansion of urban settlements, as well as rapid climate changes, there have been increased and frequent flooding, which lead to mobilisation and redistribution of some pollutants in river system and some are deposited along with the sediments flow in the floodplain transfers and storage, causing metal enrichment that may attain pollution status, $[13,18,19,21]$. Also, activities such as increased use of herbicides, insecticides, building and housing development, vehicular activities, gasoline consumption, hospital consumables, poor waste (domestic and industrial) disposal, acid mine drainage, among others, contribute in no small ways to the enrichment level of

$\triangle$ I.T. Asowata, itasowata@futa.edu.ng| 'Department of Applied Geology, Federal University of Technology, Akure (FUTA), Akure, Nigeria. ${ }^{2}$ Department of Remote Sensing and GIS, Federal University of Technology, Akure (FUTA), Akure, Nigeria. 
PHEs in these geo -media (stream sediments and floodplain soils), [9, 25, 26, 29, 49, 50, 54]. Evidently for some time now data collections relating to effect of urban development to the immediate environment such as soils and sediments have received considerable concern, owning to the fact that enrichment of PHEs have been found in these geo-media and their corresponding health effect have been scientifically found to have correlation to anthropogenic activities rather than geogenic activities, (Jayaraju et. al. 2011; [32, 40].

Stream sediments and floodplain soils reflect and represent derived materials that weathered from the rocks in the surrounding watershed, which geochemically may be a function of a variety of factors including the geology of the catchment area, flow dynamics, redox potential and landuse pattern $[36,42,47,48]$. This makes stream sediments and floodplain soils veritable part of the environment for pollution impact assessment, [6], LebretonAnberre'e et al. 2016; [2, 10].

On global assessments, several works have been carried out on the possible influence of urban expansion and its attendant effect on the relative enrichment of PHEs on these very important part of the ecosystem, that is stream sediments and floodplain soils, using scientific indexes methods such as ecological, environmental risk, contamination factors, Pollution load indexes among others, [3, $15,27,45,46,48-51]$. It was observed that the stream sediments and adjacent soils showed varying degree of between very high to extremely high toxicity risk, respectively, in these geo-media. Hence there is need for periodic and continuous assessment to mitigate environmental and human health impact.

In Nigeria, several works have been carried out both on soils and stream sediments in both urban and suburban environments particularly with emphases on the distribution pattern and pollution status of potentially harmful elements in these geologic media [33], Lapworth et al. 2012; [9, 14, 32]. In their findings, it was observed that there is considerable increase in the concentration of PHEs and attributed the sources of enrichment to be associated to urbanisation and its attendant effects. Studies have also been conducted to assess the selective mobility characteristics of trace elements in both soils and sediments of densely populated towns that are underlain by sedimentary formations, using five-step sequential extraction methods, $[4,8]$. In the results obtained, there is a considerable increase in trace elements such as $\mathrm{Pb}$, $\mathrm{Zn}, \mathrm{Cd}, \mathrm{As}, \mathrm{Cu}$ and $\mathrm{Cr}$ in both soils and sediments, and the possible uptake potentials of $\mathrm{As}$ and $\mathrm{Pb}$ in relatively low $\mathrm{pH}$ environment was high. This necessitated the need for continuous monitoring of the environments. Also, these PHEs were found to have been enriched in these geologic media by anthropogenic activities such as increase vehicular activities, uncontrolled waste (domestic and industrial), and use of leaded gasoline, among others. This research paper showed the relative spatial variation status of potentially harmful elements in the stream sediments of selected rivers that drain the study area and their adjacent floodplain soils. In this study area, there is a dearth of information on the geochemistry of stream sediments and floodplain soils. Some published works have studied the physico-chemical parameters and the geochemistry in nearby towns and cities such as Ibadan, [31], Ikire, [36], Ikorodu coastal rivers, in Lagos, [32], stream sediments and soils in Abuja, [38] among others, with less attention to this particular study area. Hence, it is important to carry out study on the spatial distribution of PHEs in the study area, particularly trying to make comparative assessment between the stream sediments and the floodplains soils that are close by.

The aim of this research is to evaluate the distribution characteristics and pollution status of potentially harmful elements in the stream sediments of rivers that drain lle-lfe area and the adjacent floodplains soils.

The study areas include the rivers that drain the lle-lfe city, particularly the Opa river, and the adjacent floodplain soils (Overbank sediments) close to the rivers. These rivers drain in dendritic pattern and have been dammed, at the premises of Obafemi Awolowo University (OAU), lle-Ife, known as the Opa dam. This dam serves as a major source of water supply to communities around, particularly the staff housing estate and students' hostels of OAU and some parts of Ife town. The rivers and the floodplain are very important part of the ecosystem that promotes agricultural (crops and livestock's) activities. The area is characterized by undulating topography, Fig. 1, which allow for free flow of runoff water and the deposition of sediments at the floodplain when the flow rate reduces.

The south-west of Nigeria generally is characterized by the tropical rainforest in the south and tropical guinea savanna in the north. The climate of the region is strongly influenced by the moisture-laden tropical maritime (mT) and dust-laden tropical continental (cT) air masses [37]. Minimum temperature over the region variation is between 21.1 and $22.9{ }^{\circ} \mathrm{C}$, while maximum temperature varied between 30.9 and $32.2^{\circ} \mathrm{C}$, and mean temperature was from 26.2 to $28.1{ }^{\circ} \mathrm{C}$. Dew point temperature values that varied from 21.3 to $24.4^{\circ} \mathrm{C}$, [1].

Ile-Ife and environs falls within the humid tropical part of Nigeria [1] and has relatively high temperature and rainfall typical of the tropical regions, having wet and dry seasons. The wet season apparently starts from around April to November. The annual rainfall variability ranges from 90 and $120 \%$ per year. The dry season, as the name goes, is characterized by relatively high temperature, with an average temperature of between 23 and $27^{\circ} \mathrm{C}$ (Adejuwon 


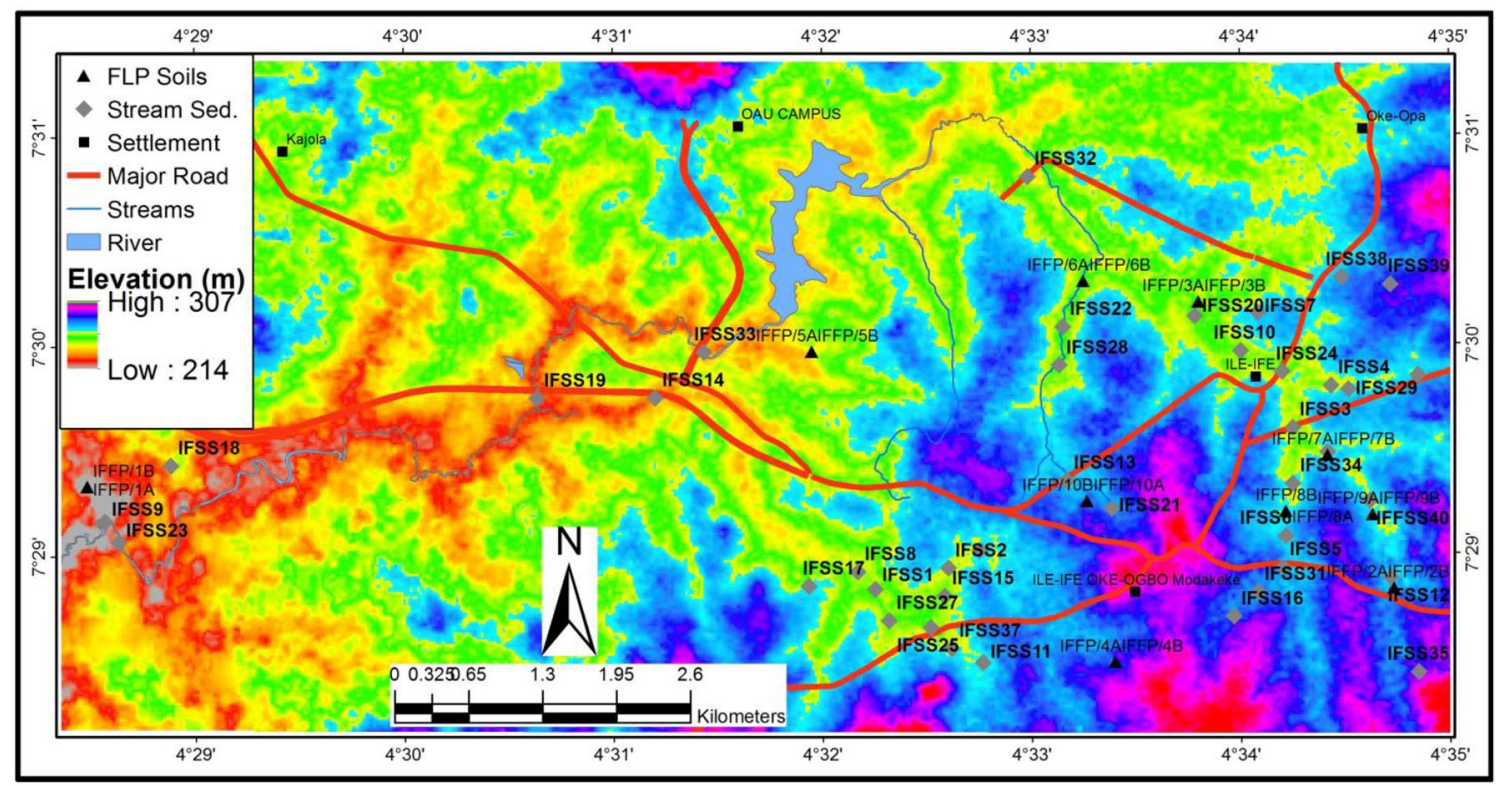

Fig. 1 Sample location map with digital elevation model (DEM). Modified after (Federal Survey, Nigeria Sheet 263 1964)

1979). The relative humidity is very high between 67 and $88 \%$. The dry season most times starts from October to March, which has duration of four months.

\subsection{Local Geology of the Study Area}

The study area is underlain by the Precambrian basement complex rocks of south-western Nigeria, [44], which represents the southern part of the Trans- Saharan mobile belt, according to $[11,12]$. It comprises of undifferentiated amphibolite schist, with pegmatite complex, biotite schist, metadiorite and granite gneiss rocks, (NGSA [30]), Fig. 2. These rocks are typical of the Nigerian south-west basement complex.

\section{Methodology}

\subsection{Sampling}

Stream sediment samples were collected from Esinmirin, Ogbogun and Opa Rivers in Ife town $(n=40)$, and floodplain soils (topsoil and subsoil) $(n=20)$ were collected from the adjacent floodplain of these rivers. For the stream sediments samples, at every sample location, three (3) subsamples were collected with an interval of two (2) meters up front and back ward. These three subsamples are mixed together and made to represent one sample. The interval for the sampling from one location to the other was taken to be $150 \mathrm{~m}$; all sediment samples were collected at the bed of the streams. After the stream sediments were taken, they were sieved right inside the stream using $>65-\mu \mathrm{m}$ mesh, and passage of the clay fraction was aided with the running stream water [32]. Similarly, floodplain soil samples were taken at a depth of $0-100 \mathrm{~cm}$, for both the topsoil $(0-20 \mathrm{~cm})$ and subsoil $(>20-100 \mathrm{~cm})$, with the aid of sampling auger. Two subsamples were taken at close range of four (4) meters and mixed together after sampling and taken as representative samples for a particular location, (Kiss and Sandor 2009; [29, 46]. These quality control measures were adopted for all the sample location in the cause of the exercise. All samples collected were well labelled in polythene plastic bottles.

The collected stream sediments and soil samples were air-dried at a room temperature $\left(26^{\circ} \mathrm{C}\right)$, pulverized using porcelain mortar and pestle after drying. The pulverized samples were sieved using $>65-\mu \mathrm{m}$ mesh and stored in polythene bags for geochemical analyses. The samples collected were accurately georeferenced using the global positioning system (GPS).

\subsection{Elemental analyses}

The air-dried stream sediment and soil samples $(0.5 \mathrm{~g})$ were digested using modified aqua regia digestion method (1:1:1 $\left.\mathrm{HNO}_{3}: \mathrm{HCl}: \mathrm{H}_{2} \mathrm{O}\right)$, which is otherwise called partial digestion method, before the elements were analysed for using ultra-trace inductively coupled plasma mass spectrometry method (ICP-ES) code AQ300, as numbered at the brochure of ACME laboratory, Canada, (https://www.acmelabs.com). Duplicate and blank samples analyses, together with certified reference materials, 


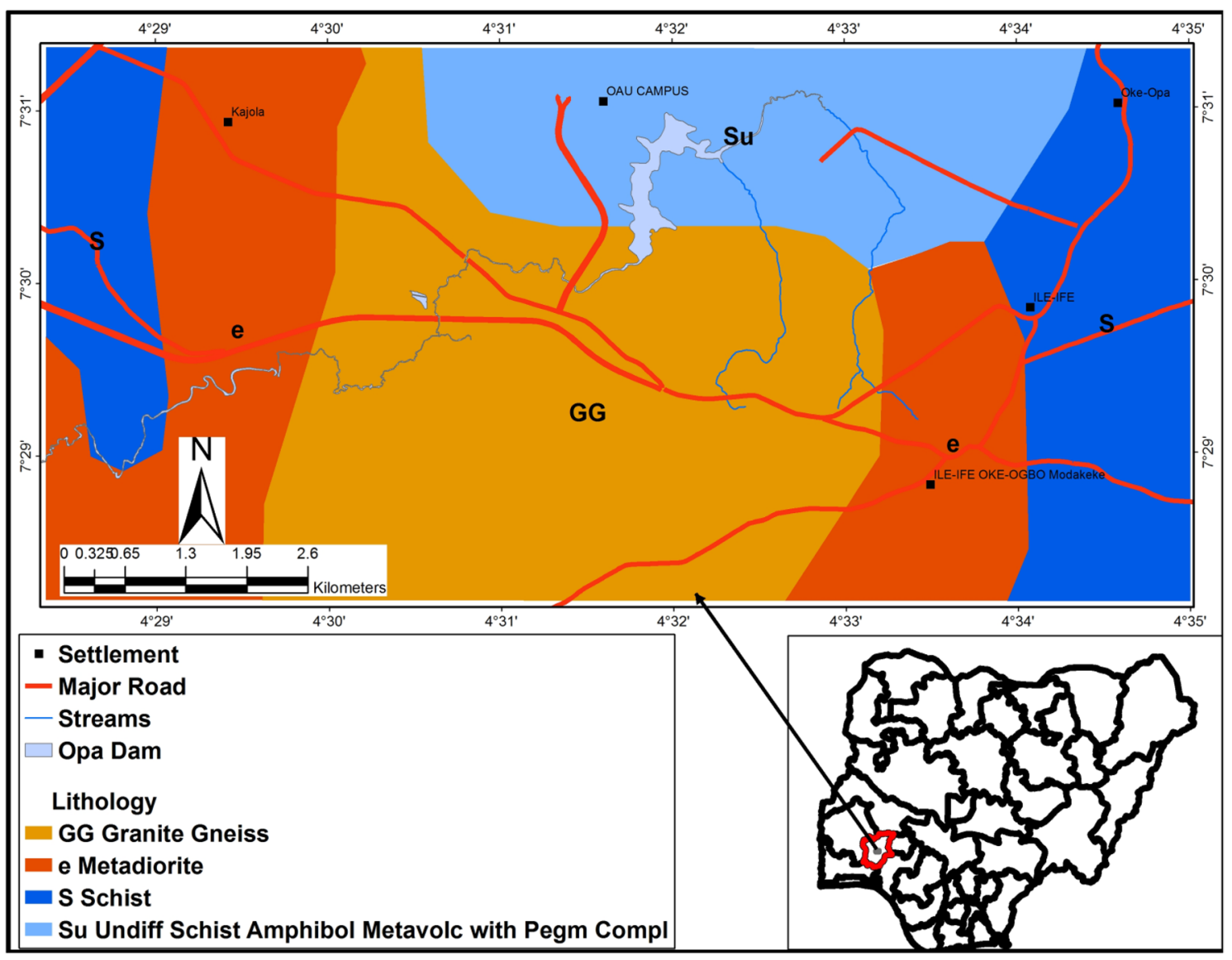

Fig. 2 Geological map of the study area, Nigeria Geologic Survey Agency (NGSA 2006)

were also analysed prior to and during the analyses of the pulp samples, for quality control measures. The results for the quality control are presented in Table 1.

The geochemical data acquired were subjected to inference statistical analyses using Grapher 9 and IBM
Statistical Package for Social Sciences (SPSS 17, of 2008). The elemental concentration distribution were georeferenced using ARCGIS software, and the relative pollution status of the elements in the study area were evaluated

Table 1 Quality control data for trace elements for stream sediments and floodplain soil

\begin{tabular}{|c|c|c|c|c|c|c|c|c|c|c|c|c|c|c|}
\hline & $\begin{array}{l}\text { Analyte } \\
\text { Unit }\end{array}$ & $\begin{array}{l}\mathrm{Cu} \\
\mathrm{ppm}\end{array}$ & $\begin{array}{l}\mathrm{Pb} \\
\mathrm{ppm}\end{array}$ & $\begin{array}{l}\mathrm{Zn} \\
\mathrm{ppm}\end{array}$ & $\begin{array}{l}\mathrm{Ni} \\
\mathrm{ppm}\end{array}$ & $\begin{array}{l}\text { Co } \\
\text { ppm }\end{array}$ & $\begin{array}{l}\mathrm{Mn} \\
\mathrm{ppm}\end{array}$ & $\begin{array}{l}\text { As } \\
\mathrm{ppm}\end{array}$ & $\begin{array}{l}\text { Th } \\
\text { ppm }\end{array}$ & $\begin{array}{l}\mathrm{Sr} \\
\mathrm{ppm}\end{array}$ & $\begin{array}{l}\mathrm{Cd} \\
\mathrm{ppm}\end{array}$ & $\begin{array}{l}\text { V } \\
\text { ppm }\end{array}$ & $\begin{array}{l}\text { La } \\
\text { ppm }\end{array}$ & $\begin{array}{l}\mathrm{Cr} \\
\mathrm{ppm}\end{array}$ \\
\hline & MDL & 1 & 3 & 1 & 1 & 1 & 2 & 2 & 2 & 1 & 0.5 & 1 & 1 & 1 \\
\hline IFSS60 & Sediment Pulp & 77 & 61 & 329 & 31 & 35 & 1503 & 4 & 4 & 35 & $<0.5$ & 203 & 36 & 139 \\
\hline IFSS60 & REP & 75 & 58 & 318 & 29 & 33 & 1468 & 5 & 4 & 34 & $<0.5$ & 197 & 34 & 136 \\
\hline IFFP36 & Sediment Pulp & 96 & 83 & 509 & 30 & 28 & 1666 & 3 & 5 & 56 & $<0.5$ & 201 & 31 & 149 \\
\hline IFFP36 & REP & 94 & 79 & 500 & 30 & 27 & 1637 & 3 & 5 & 56 & $<0.5$ & 199 & 31 & 148 \\
\hline STD OREAS45EA & STD & 722 & 12 & 33 & 425 & 53 & 411 & 17 & 8 & 4 & $<0.5$ & 321 & 7 & 912 \\
\hline STD DS11 & STD & 145 & 137 & 345 & 76 & 13 & 1008 & 45 & 7 & 66 & 2.2 & 48 & 16 & 57 \\
\hline STD OREAS45EA & STD & 688 & 11 & 31 & 413 & 51 & 397 & 13 & 7 & 4 & $<0.5$ & 314 & 8 & 892 \\
\hline STD DS11 & STD & 145 & 139 & 341 & 76 & 13 & 1016 & 43 & 7 & 68 & 2.2 & 49 & 17 & 58 \\
\hline BLK & BLK & $<1$ & $<3$ & $<1$ & $<1$ & $<1$ & $<2$ & $<2$ & $<2$ & $<1$ & $<0.5$ & $<1$ & $<1$ & $<1$ \\
\hline BLK & BLK & $<1$ & $<3$ & $<1$ & $<1$ & $<1$ & $<2$ & $<2$ & $<2$ & $<1$ & $<0.5$ & $<1$ & $<1$ & $<1$ \\
\hline
\end{tabular}

STD, standard; BLK, blank samples; MDL, minimum detection limit; Rep, repeated 
using geochemical indices such as metal ratio and geoaccumulation index.

The pollution status of PHEs in the floodplain soils and stream sediments in the study area was assessed using Geo-accumulation index (l-geo) equation [28];

$\mathrm{I}-\mathrm{geo}=\log 2 \mathrm{Cn} / 1.5 \mathrm{Bn}$

where $\mathrm{I}$-geo = geo-accumulation index, $\mathrm{Cn}=$ measured concentration of the element in the geo media, $\mathrm{Bn}=$ represent the background average. Here in this work, the average shale concentration by [55] was used $1.5=$ constant in the equation, which is background matrix correction.

I-geo is classified into 7 groups, $1=\leq 0$ is practically unpolluted; $0<\mathrm{l}$-geo $<1$ is unpolluted to moderately polluted; $1<\mathrm{I}$-geo $<1$ is moderately polluted; $2<\mathrm{I}$-geo $<3$ : moderately to strongly polluted; $3<1-$ geo $<4$ : strongly polluted; $4<$ I-geo $<5$ : strongly to extremely polluted and $5<$ l-geo: extremely polluted $[28,53]$.

Metal ratio (MR), it is an environmental impact assessment index that is calculated by comparing the observed elements concentration with calculated background values or with average shale content (ASC). The outcome will be used to know if there is relative enrichment or depletion in the concentration of elements analysed in the study area. The graduation is such that when $M R$ is $<1$, it indicate low metal enrichment which can also imply ideal concentration of elements while when the ratio is $>1$ is suggest elevated metal concentration

In the study (Olatunji et al. [34]),

$\mathrm{MR}=\mathrm{Cn} / \mathrm{ASC}$

where $\mathrm{Cn}=$ Concentration of the PHE; ASC = Average Shale Concentration, according to (Turekian and Wedepohl [52]).

\section{Results and discussion}

The concentration of potentially harmful elements (PHEs) in floodplain soils and stream sediments $(\mathrm{Cu}, \mathrm{Pb}, \mathrm{Zn}, \mathrm{Ni}$, $\mathrm{Co}, \mathrm{Mn}, \mathrm{As}, \mathrm{Th}, \mathrm{Sr}, \mathrm{Cd}, \mathrm{V}$, La and $\mathrm{Cr}$ ) in the study area is presented in Table 2. From the results of the floodplain topsoil in ppm, $\mathrm{Cu}$ is in the range 10.0-180.0; mean, 71.1, Pb, 17.1-255.0; 93.5, Zn, 83.0-3122.2; 826.0, Ni, 8.0-45.0; 25.3, Co, 7.0-48.0; 24.6, Mn, 245.0-3051.0; 1322.8, As, 2.1-4.0; 3.1, Th, 2.0-8.0; 4.3, Sr, 9.0-88.0; 32.9, Cd 0.5-6.0; 1.42, V, 28.0-204.0; 142.6, La, 22.0-38.0, 32.2 and Cr, 22.0-187.0. Also, the results for the floodplain sub-soils shown that $\mathrm{Cu}$ range from 30.0-203.1; mean of 76.6, $\mathrm{Pb}, 16.0-214.0 ; 77.9$, Zn, 59.1-2351.0; 622.3, Ni, 13,0-46.2; 27.2, Co, 10.0-46.0, 28.7, Mn, 491.0-1894.0; 1190, As, 2.0-5.0; 3.4, Th, 3.0-6.0; 4.5, Sr, 12.0-73.0, 30.6, Cd, 0.5-6.1; 1.28, V, 35.0-232.0; 165.5, La, 20.0-42.0; 34.0, and Cr, 34.0-216.0; 128.5.. Similarly, the results for the stream sediments in the study area, shown that, $\mathrm{Cu}, 22.1-257.0 ; 70.3, \mathrm{~Pb}, 15.0-172.0 ; 67.3, \mathrm{Zn}$, 65.0-1285.0; 357.8, Ni, 15.1-36.0; 24.9, Co, 9.1-69.0; 29.3, Mn, 199.0-6023.0; 2138.4, As, 2.0-6.0; 3.3 Th, 3.0-18.0; 5.9, $\mathrm{Sr}, 13.0-216.0 ; 53.4, \mathrm{Cd}, 0.5-3.0 ; 0.7, \mathrm{~V}, 64.0-257.0 ; 161.7$, La, 16.0-62.1;31.6 and $\mathrm{Cr}, 60.0-394.1 ; 132.8$. These results showed that there were relative variations in the distribution pattern of these PHEs in the topsoil, subsoil and stream sediments from one sampling site to the other. Generally, for the floodplain soils (top and sub) and the stream sediments, it was observed that the decreasing trend of average contents of PHEs studied showed that $\mathrm{Mn}>\mathrm{Zn}>\mathrm{V}>\mathrm{Cr}>\mathrm{Pb}>\mathrm{La}>\mathrm{Sr}>\mathrm{Cu}>\mathrm{Ni}>\mathrm{Co}>\mathrm{Th}>\mathrm{As}>\mathrm{Cd}$.

Considering the floodplain soils, the results of $\mathrm{Cu}$ in (ppm) showed the highest concentration of $C u$ was found in location IFFP7A (180.0) while the lowest concentration was found in IFFP10B (10.0). Other locations in the
Table 2 Summary results of potentially harmful elements in floodplain soils and stream sediments

\begin{tabular}{|c|c|c|c|c|c|c|c|c|c|c|c|c|}
\hline & \multicolumn{4}{|c|}{ Topsoils $(n=10)$} & \multicolumn{4}{|c|}{ Subsoils $(n=10)$} & \multicolumn{4}{|c|}{ Stream Sediments $(n=40)$} \\
\hline & Min & Max & Mean & SD & Min & Max & Mean & SD & Min & Max & Mean & SD \\
\hline $\mathrm{Cu}$ & 10.0 & 180.0 & 71.1 & 42.6 & 30.0 & 203.1 & 76.6 & 46.9 & 22.1 & 257.0 & 70.3 & 41.8 \\
\hline $\mathrm{Pb}$ & 17.1 & 255.0 & 93.5 & 87.1 & 16.0 & 214.0 & 77.9 & 59.8 & 15.0 & 172.0 & 67.3 & 46.6 \\
\hline $\mathrm{Zn}$ & 83.0 & 3122.2 & 826.0 & 1145.6 & 59.1 & 2351.0 & 622.3 & 778.6 & 65.0 & 1285.0 & 357.8 & 288.1 \\
\hline $\mathrm{Ni}$ & 8.0 & 45.0 & 25.3 & 9.4 & 13.0 & 46.2 & 27.2 & 8.9 & 15.1 & 36.0 & 24.9 & 5.5 \\
\hline Co & 7.0 & 48.0 & 24.6 & 13.8 & 10.0 & 46.0 & 28.7 & 12.2 & 9.1 & 69.0 & 29.3 & 13.2 \\
\hline $\mathrm{Mn}$ & 245.0 & 3051.0 & 1322.8 & 864.6 & 491.0 & 1894.0 & 1190 & 585.1 & 199.0 & 6023.0 & 2138.4 & 1425.5 \\
\hline As & 2.1 & 4.0 & 3.1 & 0.7 & 2.0 & 5.0 & 3.4 & 0.8 & 2.0 & 6.0 & 3.3 & 1.0 \\
\hline Th & 2.0 & 8.0 & 4.3 & 1.9 & 3.0 & 6.0 & 4.5 & 1.2 & 3.0 & 18.0 & 5.9 & 2.4 \\
\hline $\mathrm{Sr}$ & 9.0 & 88.0 & 32.9 & 22.5 & 12.0 & 73.0 & 30.6 & 17.0 & 13.0 & 216.0 & 53.4 & 39.8 \\
\hline $\mathrm{Cd}$ & 0.5 & 6.0 & 1.42 & 2.0 & 0.5 & 6.1 & 1.28 & 1.8 & 0.5 & 3.0 & 0.7 & 0.5 \\
\hline V & 28.0 & 204.0 & 142.6 & 65.0 & 35.0 & 232.0 & 165.5 & 61.9 & 64.0 & 257.0 & 161.7 & 48.5 \\
\hline La & 22.0 & 38.0 & 32.2 & 5.9 & 20.0 & 42.0 & 34.0 & 5.7 & 16.0 & 62.1 & 31.6 & 7.5 \\
\hline $\mathrm{Cr}$ & 22.0 & 187.0 & 108.8 & 46.8 & 34.0 & 216.0 & 128.5 & 46.3 & 60.0 & 394.1 & 132.8 & 52.8 \\
\hline
\end{tabular}


floodplain with relatively higher concentration of $\mathrm{Cu}$ were IFFP9A (80.0) and IFFP3A (68.0), as compared to other location with, relatively, low concentration in ppm, IFFP10A (10.0) and IFFP10B (11.5). Pb (ppm) concentration showed varying concentrations, with locations IFFP1A (255.0), IFFP7A (219.0) and IFFP7B (214.0), respectively, exhibiting relatively higher concentration among other locations. Locations IFFP9A (39.0) and IFFP6B (19.0) were found to be of low concentration. $\mathrm{Zn}$ (ppm) showed varying concentration, with locations such as IFFP1A (3122.0), IFFP7A (2824.0) and IFFP7B (2351.0) showing areas of higher concentration of Zn. While locations IFFP2B (59.0) and IFFP7B (2351.0) exhibited relatively lower concentration of $\mathrm{Zn}$. Similar variation in spatial distribution where found in the other PHEs analysed in the floodplain soils.

The concentration of PHEs in stream sediments in the study area also showed spatial variations from one location to the other. Locations with relatively higher concentration for $\mathrm{Cu}(\mathrm{ppm})$ include: IFSS13 (257.0), IFSS28 (168.0) and IFSS21 (152.0), while locations with relatively low concentrations were IFSS17 (22.0), IFSS7 (28.0) and IFSS23 (31.0). Pb (ppm) in the stream sediments exhibits relatively higher concentrations in locations IFSS36 (172.0), IFSS13 (168.0), IFSS2 (167.0) and IFSS15 (162.0) among other locations. While relatively lower concentrations of $\mathrm{Pb}$ were found in locations IFSS30 (15.0), IFSS18 (20.0) and IFSS4 (21.0). $\mathrm{Zn}$ in the stream sediments showed relatively higher concentration in locations IFSS13 (1285.0), IFSS21 (1232.0), IFSS28 (765.0), IFSS2 (665.0) and IFSS16 (553.0) among other locations. While relatively lower concentration of Zn were found in locations IFSS30 (65.0), IFSS29 (68.0) and IFSS26 (76.0). These variations in spatial distributions of PHEs were exhibited by all other PHEs analysed, as summarily seen in Table 2 .

\subsection{Spatial distribution of potentially harmful elements in floodplain soils}

The results of the analysed elements were presented in geospatial maps, using Arc-GIS 10.0 software, Fig. 3a-m to express visually the spatial distribution of PHEs in the floodplain soils (top and sub) in the study area. The concentrations were plotted as bi-pie chart points to represent both the results for topsoil and subsoils, and a mean boundary was established to reduce over generalisation of errors in the study area. There was significant enrichment of $\mathrm{Cu}(\mathrm{ppm})$ in the main river floodplain that drain the city centre and other developed parts of the town relative to the outskirt of the town, which suggest influence of urban activities on the enrichment of $\mathrm{Cu}$ in the study area. Also, it was observed that in many of the locations, the concentration in ppm for $\mathrm{Cu}$ in subsoils was slightly higher than the topsoils results, suggesting that $\mathrm{Cu}$ in the floodplain is significantly enriched in both the topsoil and the subsoil. Whereas in some other locations, there were presences of higher concentration in the topsoil compare to the subsoil.

Similarly, there were variations in the spatial distribution of $\mathrm{Pb}$ from one location to the other. Significant enrichment of $\mathrm{Pb}$ was found also in the river that drains the urban core areas relative to the outskirt of the town. Also, the result for the topsoil in many of the locations was found to be higher in concentration as observed in locations IFFP1A (255.0) and IFFP1B (17.0), IFFP4A (128.0) and IFFP4B (97.0) among other locations compare to the concentration of $\mathrm{Pb}(\mathrm{ppm})$ in the subsoil, except in locations IFFP9A (39.0) and IFFP9B (60.0), IFFP2A (23.0) and IFFP2B (25.0) where the subsoils $\mathrm{Pb}$ concentration was higher that the topsoil. These suggest the influence of urban activities on the enrichment of $\mathrm{Pb}$ in the area. Significant amount of enrichment of $\mathrm{Zn}, \mathrm{Ni}, \mathrm{Co}, \mathrm{Mn}, \mathrm{As}, \mathrm{Th}, \mathrm{Cd}, \mathrm{V}$, La and $\mathrm{Cr}$ was spatially found to be high in the floodplain soil around the core urban area where concentration reduces as one move out of the urban area. Higher concentrations of these PHEs were found in the topsoil in many of the locations relative to the subsoil, Fig. 3a-m. The relative variation and higher concentration of these elements in the topsoil compared to the subsoil is of concern, as it poses health risk due to the easy bio-uptake of biologic materials such as agricultural plants and grassing animals which derive its nutrients from the topsoil relative to the subsoil.

\subsection{Spatial distribution of potentially harmful elements in stream sediments}

The results for the stream sediments elemental analyses were also presented in geospatial maps, Fig. 4a-m for visual spatial distribution interpretation. The concentrations were plotted in a five step gradation points to represent varying concentration pattern from one location to the other. It was observed that $\mathrm{Cu}, \mathrm{Pb}, \mathrm{Zn}, \mathrm{Ni}, \mathrm{As}, \mathrm{Sr}, \mathrm{V}$ and $\mathrm{Cr}$ exhibit similar pattern of enrichment as seen in the geospatial plots, suggesting that the enrichment of these elements may have been influenced by anthropogenic activities that are in high attendant measures in urban environment. However, Co, Mn, Th and La exhibit slightly different patterns in the geospatial distribution map. These may have been attributed to localized sources enrichment in the stream sediments in the study area. $\mathrm{Cu}(\mathrm{ppm})$, location IFFP13 (257.0), IFFP28 (168.0), IFFP21 (152.0) IFFP15 (99.0) and IFFP36 (87.0) among other locations exhibits similar pattern of elemental enrichment with Pb, IFFP13 (168), IFFP21 (124.0), IFFP15 (162.0), IFFP28 (135.0) and IFFP36 (176.0); Zn, IFFP13 (1285.0), IFFP21 (1232.0), IFFP15 (722.0), IFFP28 (765.0) and IFFP36 (564.0), As, IFFP13 (6.0), IFFP21 (4.0), IFFP15 (3.0), IFFP28 (4.0) and IFFP36 (5.0). The 

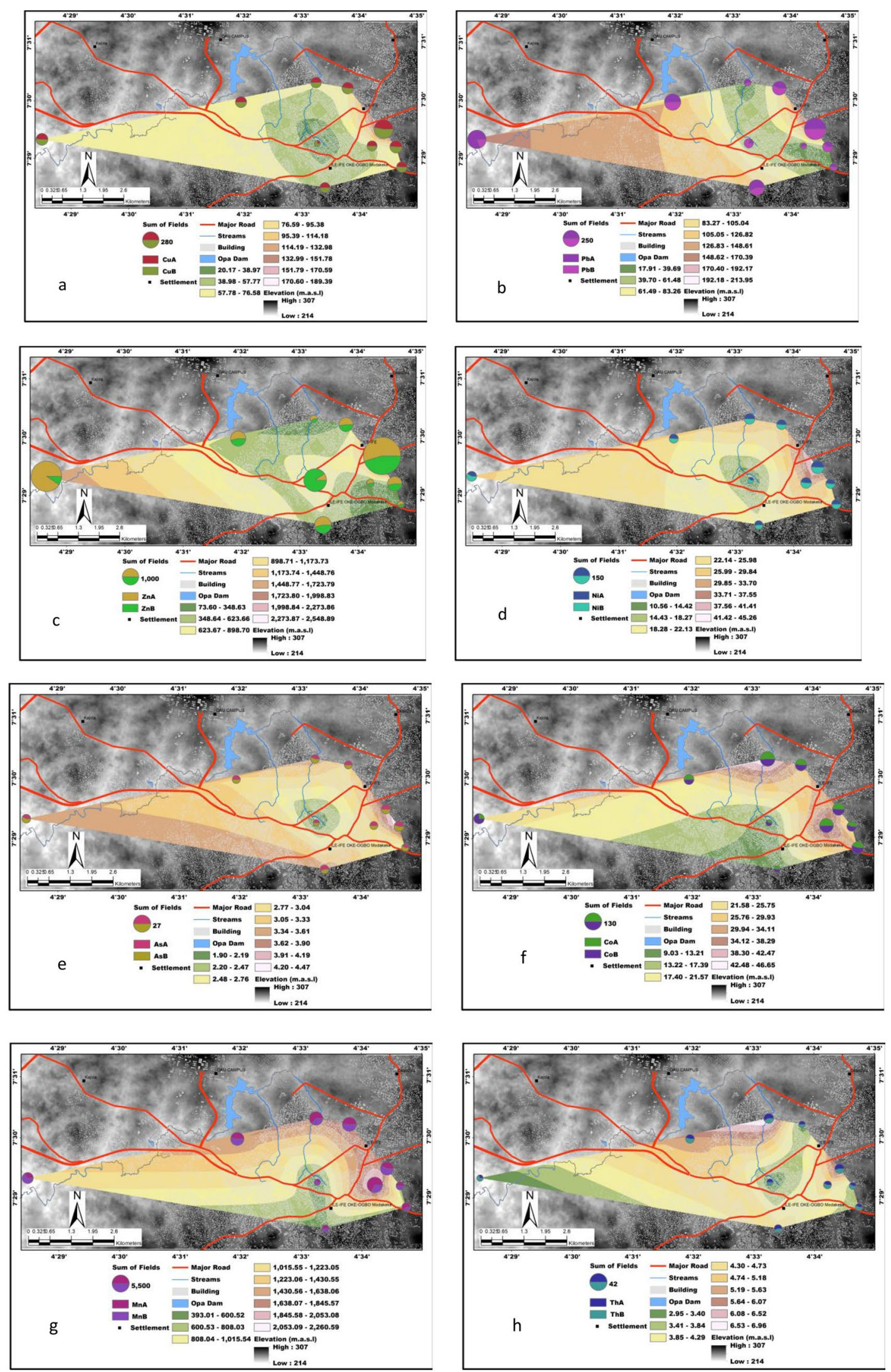

Fig. 3 a-m Potentially harmful elements distribution pattern of floodplain soils in the study area. Please note PHEs such as CuA represent topsoils result while CuB represents subsoils. This is represented in the other potentially harmful elements 

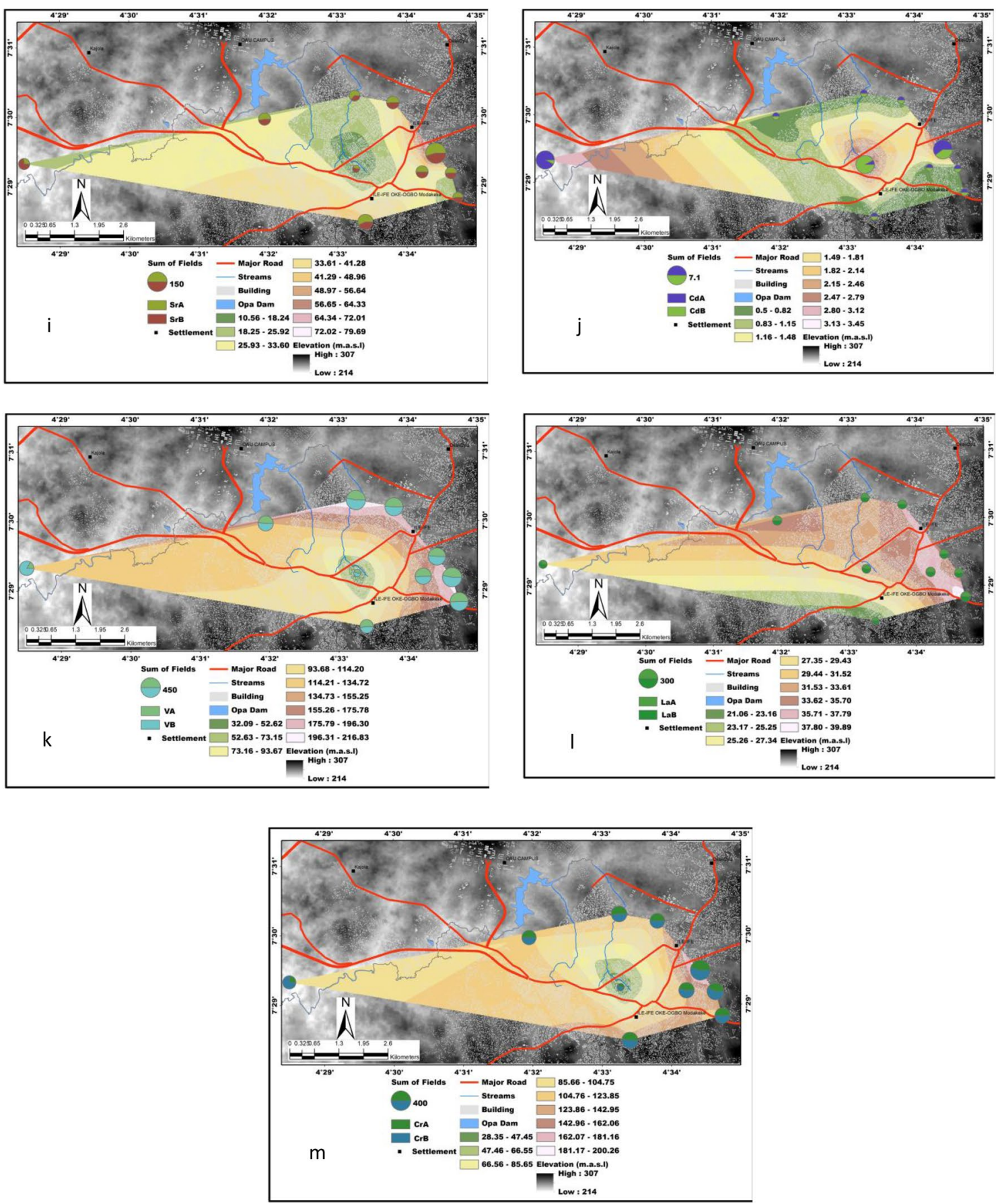

Fig. 3 (continued)

other elements ( $\mathrm{Ni}, \mathrm{Sr}, \mathrm{V}$ and $\mathrm{Cr}$ ) also exhibits similar trend of enrichment, Fig. 4a-m.

The analysed PHEs for the floodplain soils (topsoil and subsoil) and stream sediments were further subjected to inter elemental association, using coefficient of determination $\left(R^{2}\right)$, Pearson correlation (PC) and principal component analysis (PCA). Effort was made to compare the coefficient of determination among the floodplain soils (topsoil and subsoil) and stream sediment in the study area, Fig. $5 \mathrm{a}-\mathrm{d}$. For $\mathrm{Pb} / \mathrm{Zn}$, topsoil $\left(R^{2}=0.85\right)$ subsoil $\left(R^{2}=0.68\right)$ and stream sediments $\left(R^{2}=0.53\right), \mathrm{Cr} / \mathrm{Zn}$, topsoil $\left(R^{2}=0.02\right)$ subsoil $\left(R^{2}=0.0006\right)$ and stream sediments $\left(R^{2}=0.37\right), \mathrm{Co} / \mathrm{Mn}$, topsoil $\left(R^{2}=0.25\right)$ subsoil $\left(R^{2}=0.2\right)$ and stream sediments $\left(R^{2}=0.77\right)$ and $\mathrm{V} / \mathrm{Cr}$, topsoil $\left(R^{2}=0.34\right)$ subsoil $\left(R^{2}=0.10\right)$ and stream sediments $\left(R^{2}=0.61\right)$. It was observed that strong to very strong correlation were 

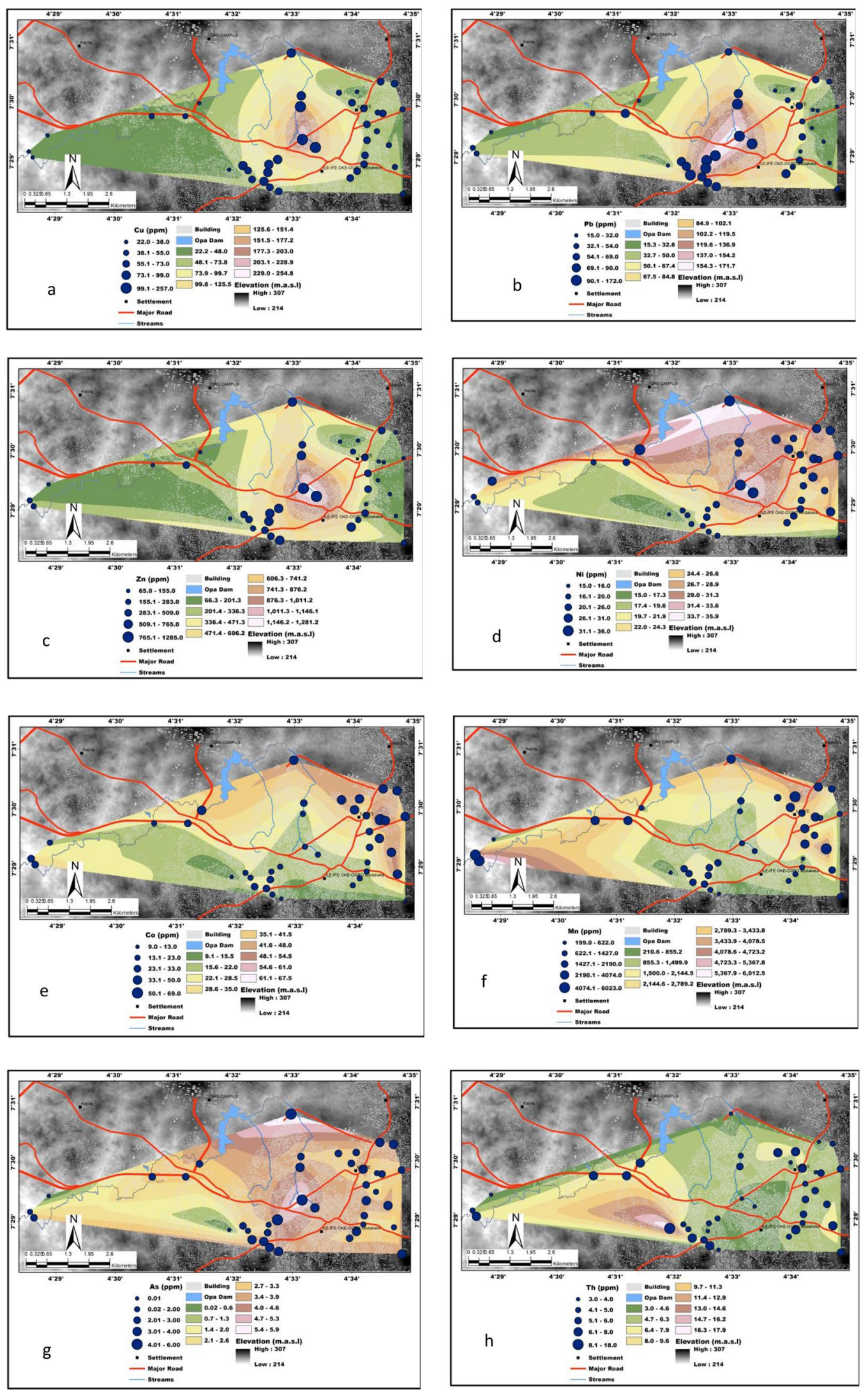

Fig. 4 a-m Potentially harmful elements distribution pattern of stream sediments 

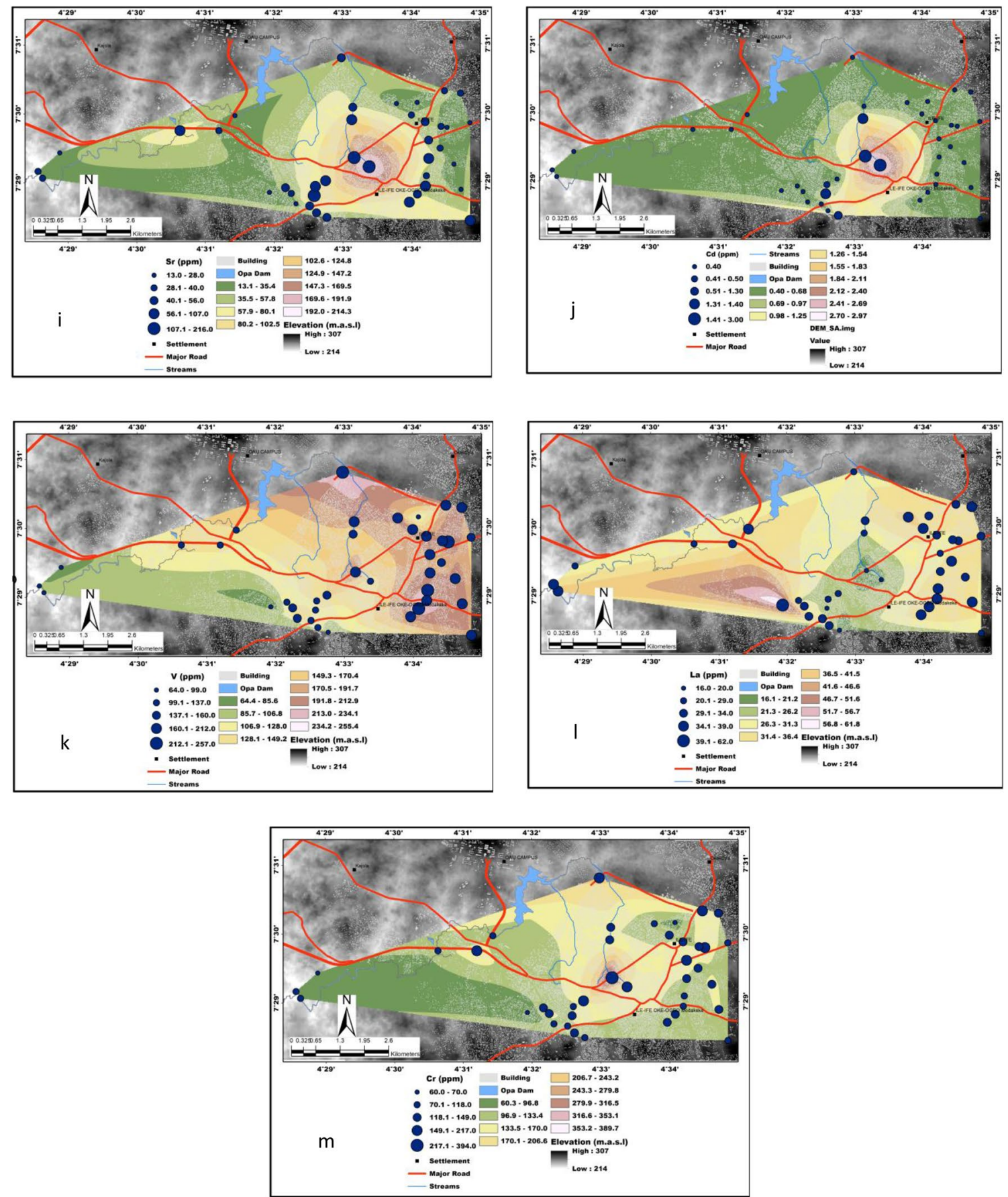

Fig. 4 (continued)

observed for topsoil, subsoil and stream sediments in the study area for $\mathrm{Pb} / \mathrm{Zn}$. Relatively weak $R^{2}$ were found in $\mathrm{Cr} / \mathrm{Zn}$ for topsoil and subsoil while fairly strong $R^{2}$ was found in stream sediments. Similarly, weak $R^{2}$ were found in topsoil and subsoil for $\mathrm{Co} / \mathrm{Mn}$ as against stream sediments. Also, for $\mathrm{V} / \mathrm{Cr}$, weak $R^{2}$ were found in topsoil and subsoil relative to strong correlation for stream sediments. This implies that elements with strong correlation may have been enriched in the geo-media by similar source where the weakly correlated elements may not have been enriched in the environment by similar source(s).

The correlation coefficient matrix for the floodplain topsoil, subsoil and stream sediments elements are presented in Tables 3, 4 and 5. There are wide variations in the correlation coefficient (Rsq) between elements pairs. The $\mathrm{r}$ readings range from -0.01 to 0.98 for topsoil, -0.01 to 0.82 

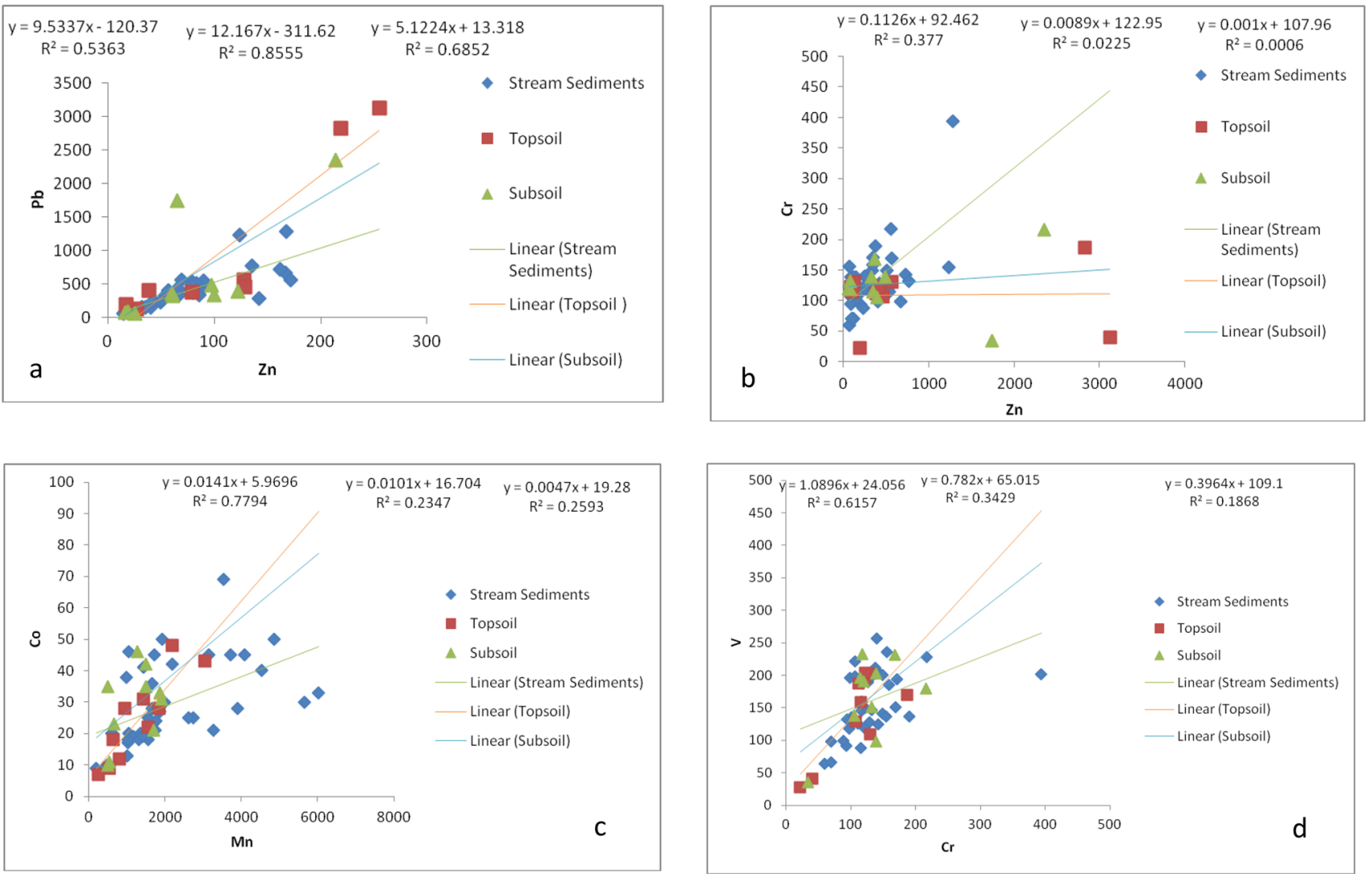

Fig. 5 a-d Bivariate plots of selected potentially harmful elements in the geo-media studied

Table 3 Correlation coefficients of elements in the topsoils

\begin{tabular}{|c|c|c|c|c|c|c|c|c|c|c|c|c|c|}
\hline & $\mathrm{Cu}$ & $\mathrm{Pb}$ & $\mathrm{Zn}$ & $\mathrm{Ni}$ & Co & $\mathrm{Mn}$ & As & Th & $\mathrm{Sr}$ & $\mathrm{Cd}$ & V & $\mathrm{La}$ & $\mathrm{Cr}$ \\
\hline $\mathrm{Cu}$ & 1.00 & & & & & & & & & & & & \\
\hline $\mathrm{Pb}$ & 0.61 & 1.00 & & & & & & & & & & & \\
\hline $\mathrm{Zn}$ & 0.66 & 0.92 & 1.00 & & & & & & & & & & \\
\hline $\mathrm{Ni}$ & 0.87 & 0.33 & 0.40 & 1.00 & & & & & & & & & \\
\hline Co & 0.25 & -0.31 & -0.22 & 0.68 & 1.00 & & & & & & & & \\
\hline $\mathrm{Mn}$ & 0.14 & -0.20 & -0.19 & 0.55 & 0.88 & 1.00 & & & & & & & \\
\hline As & 0.63 & 0.44 & 0.36 & 0.49 & -0.02 & 0.01 & 1.00 & & & & & & \\
\hline Th & 0.45 & 0.05 & 0.01 & 0.61 & 0.57 & 0.39 & 0.36 & 1.00 & & & & & \\
\hline $\mathrm{Sr}$ & 0.85 & 0.45 & 0.40 & 0.78 & 0.21 & 0.15 & 0.68 & 0.63 & 1.00 & & & & \\
\hline $\mathrm{Cd}$ & 0.54 & 0.87 & 0.98 & 0.33 & -0.19 & -0.16 & 0.21 & -0.08 & 0.23 & 1.00 & & & \\
\hline V & 0.37 & -0.37 & -0.34 & 0.61 & 0.70 & 0.48 & 0.27 & 0.38 & 0.33 & -0.39 & 1.00 & & \\
\hline La & 0.27 & -0.44 & -0.34 & 0.46 & 0.66 & 0.54 & -0.21 & 0.23 & 0.19 & -0.37 & 0.68 & 1.00 & \\
\hline $\mathrm{Cr}$ & 0.73 & 0.06 & 0.02 & 0.84 & 0.55 & 0.38 & 0.60 & 0.66 & 0.82 & -0.11 & 0.78 & 0.48 & 1.00 \\
\hline
\end{tabular}

for subsoil and $-0.01-0.87$ for stream sediments in the study area. For the topsoil, fairly strong to very strong positive correlation were found among $\mathrm{Zn}$ and $\mathrm{Cd}(\mathrm{Rsq}=0.98)$, $\mathrm{Pb}$ and $\mathrm{Zn}(\mathrm{Rsq}=0.92), \mathrm{Co}$ and $\mathrm{Mn}(\mathrm{Rsq}=0.88), \mathrm{Cu}$ and $\mathrm{Pb}(\mathrm{Rsq}=0.61)$ among others, Table 3, also for subsoil, $\mathrm{Pb}$ and $\mathrm{Sr}(\mathrm{Rsq}=0.82), \mathrm{Cu}$ and $\mathrm{Sr}(\mathrm{Rsq}=0.90), \mathrm{Zn}$ and $\mathrm{Cd}$ (Rsq=0.80), Ni and Cu (Rsq=0.82), As and V (Rsq=0.81), Cr and $\mathrm{Cu}(\mathrm{Rsq}=0.82)$ and $\mathrm{V}$ and $\mathrm{Cr}(\mathrm{Rsq}=0.59)$ and similarly for stream sediments, $\mathrm{Zn}$ and $\mathrm{Cu}(\mathrm{Rsq}=0.87), \mathrm{Pb}$ and $\mathrm{Zn}$ $(\mathrm{Rsq}=0.82), \mathrm{Zn}$ and $\mathrm{Sr}(\mathrm{Rsq}=0.87), \mathrm{Zn}$ and $\mathrm{Cd}(\mathrm{Rsq}=0.78)$ $\mathrm{Sr}$ and $\mathrm{Cd}(\mathrm{Rsq}=0.86)$, As and $\mathrm{Cr}(\mathrm{Rsq}=0.61)$ and $\mathrm{Co}$ and $\mathrm{Mn}(\mathrm{Rsq}=0.51)$. The relative fairly strong to very strong correlation coefficient of these elements as represented in bold values, as presented in Tables 3, 4 and 5, suggests 
Table 4 Correlation coefficients of elements in the subsoils

\begin{tabular}{llrrrrrrrrrrrr}
\hline & $\mathrm{Cu}$ & $\mathrm{Pb}$ & $\mathrm{Zn}$ & $\mathrm{Ni}$ & $\mathrm{Co}$ & $\mathrm{Mn}$ & $\mathrm{As}$ & $\mathrm{Th}$ & $\mathrm{Sr}$ & $\mathrm{Cd}$ & $\mathrm{V}$ & $\mathrm{La}$ & $\mathrm{Cr}$ \\
\hline $\mathrm{Cu}$ & 1.00 & & & & & & & & & & & & \\
$\mathrm{~Pb}$ & $\mathbf{0 . 7 8}$ & 1.00 & & & & & & & & & & \\
$\mathrm{Zn}$ & $\mathbf{0 . 6 1}$ & $\mathbf{0 . 7 3}$ & 1.00 & & & & & & & & & & \\
$\mathrm{Ni}$ & $\mathbf{0 . 8 2}$ & 0.41 & 0.24 & 1.00 & & & & & & & & & \\
$\mathrm{Co}$ & 0.22 & -0.31 & -0.34 & $\mathbf{0 . 6 9}$ & 1.00 & & & & & & & & \\
$\mathrm{Mn}$ & 0.49 & 0.45 & 0.11 & $\mathbf{0 . 6 8}$ & 0.48 & 1.00 & & & & & & & \\
$\mathrm{As}$ & 0.48 & 0.08 & -0.13 & $\mathbf{0 . 5 3}$ & 0.37 & 0.15 & 1.00 & & & & & & \\
$\mathrm{Th}$ & 0.44 & 0.27 & 0.06 & $\mathbf{0 . 6 0}$ & 0.44 & 0.45 & 0.34 & 1.00 & & & & & \\
$\mathrm{Sr}$ & $\mathbf{0 . 9 0}$ & $\mathbf{0 . 8 2}$ & 0.56 & $\mathbf{0 . 7 4}$ & 0.06 & 0.48 & 0.31 & 0.38 & 1.00 & & & & \\
$\mathrm{Cd}$ & 0.05 & 0.25 & $\mathbf{0 . 8 0}$ & $-\mathbf{0 . 2 4}$ & -0.44 & -0.22 & -0.46 & -0.25 & -0.02 & 1.00 & & & \\
$\mathrm{~V}$ & 0.35 & -0.13 & -0.43 & 0.58 & $\mathbf{0 . 7 2}$ & 0.34 & $\mathbf{0 . 8 1}$ & 0.29 & 0.12 & -0.68 & 1.00 & & \\
$\mathrm{La}$ & 0.04 & -0.20 & -0.07 & 0.19 & 0.48 & 0.26 & -0.09 & -0.08 & -0.21 & 0.06 & 0.27 & 1.00 \\
$\mathrm{Cr}$ & $\mathbf{0 . 8 2}$ & 0.48 & 0.15 & 0.80 & 0.33 & 0.33 & $\mathbf{0 . 7 4}$ & 0.45 & $\mathbf{0 . 8 1}$ & -0.42 & $\mathbf{0 . 5 9}$ & -0.15 & 1.00 \\
\hline
\end{tabular}

Table 5 Correlation coefficients of elements in the stream sediments

\begin{tabular}{|c|c|c|c|c|c|c|c|c|c|c|c|c|c|}
\hline Elements & $\mathrm{Cu}$ & $\mathrm{Pb}$ & $\mathrm{Zn}$ & $\mathrm{Ni}$ & Co & $\mathrm{Mn}$ & As & Th & $\mathrm{Sr}$ & $\mathrm{Cd}$ & V & La & $\mathrm{Cr}$ \\
\hline $\mathrm{Cu}$ & 1 & & & & & & & & & & & & \\
\hline $\mathrm{Pb}$ & 0.68 & 1.00 & & & & & & & & & & & \\
\hline $\mathrm{Zn}$ & 0.87 & 0.82 & 1.00 & & & & & & & & & & \\
\hline $\mathrm{Ni}$ & 0.36 & -0.11 & 0.18 & 1.00 & & & & & & & & & \\
\hline Co & -0.24 & -0.46 & -0.43 & 0.55 & 1.00 & & & & & & & & \\
\hline $\mathrm{Mn}$ & -0.29 & -0.22 & -0.21 & 0.03 & 0.51 & 1.00 & & & & & & & \\
\hline As & 0.53 & 0.31 & 0.47 & 0.30 & -0.04 & 0.03 & 1.00 & & & & & & \\
\hline Th & -0.35 & -0.29 & -0.40 & -0.39 & -0.14 & -0.11 & -0.17 & 1.00 & & & & & \\
\hline $\mathrm{Sr}$ & 0.77 & 0.64 & 0.87 & 0.21 & -0.37 & -0.20 & 0.39 & -0.38 & 1.00 & & & & \\
\hline $\mathrm{Cd}$ & 0.76 & 0.46 & 0.78 & 0.33 & -0.24 & -0.22 & 0.37 & -0.30 & 0.86 & 1.00 & & & \\
\hline V & 0.21 & -0.18 & -0.04 & 0.41 & 0.40 & 0.00 & 0.35 & -0.18 & 0.00 & -0.08 & 1.00 & & \\
\hline La & -0.58 & -0.58 & -0.64 & -0.18 & 0.15 & 0.08 & -0.35 & 0.79 & -0.61 & -0.53 & 0.01 & 1.00 & \\
\hline $\mathrm{Cr}$ & 0.76 & 0.39 & 0.58 & 0.44 & 0.04 & -0.05 & 0.61 & -0.32 & 0.43 & 0.48 & 0.44 & -0.47 & 1 \\
\hline
\end{tabular}

that these elements may have been enriched in the geomedia by similar sources.

In the same vein, the PHEs analysed were subjected to PCA for further assessment of association of these elements, Tables 6 and 7. The factor analyses for the stream sediments exhibit four groups of PHEs, Table 6; the first group comprises $\mathrm{Cu}, \mathrm{Pb}, \mathrm{Zn}, \mathrm{As}, \mathrm{Sr}, \mathrm{Cd}$ and $\mathrm{Cr}$, accounting for $44.12 \%$ total variance of eigen value. These groups of elements suggest that they might have been enriched by same sources, such as input from leaded gasoline, domestic waste disposal, batteries, waste steel, traffic activities, hospital chemicals, pesticides and the used herbicides close by. The presence $\mathrm{Pb}, \mathrm{As}$ and $\mathrm{Cd}$ in the stream sediments are of great concern, owning to the fact that these elements are very hazardous to the environment and are regarded as high priority toxic elements, $[35,45]$. The second group is made of $\mathrm{Ni}, \mathrm{V}$ and $\mathrm{Co}$, which account for $19.46 \%$ total variance of eigen value. These elements might have enriched in the stream sediment by washout from automobile activities and other iron steel works, which correspond to the findings of [4, 32]. The third group of elements, Th and La, account for $10.15 \%$ total variance of eigen value. These two element, though not significantly much in the stream sediments, may have been enriched in the stream sediment by weathered granite-rich rock that underlain the study area. The fourth group, which is $\mathrm{Mn}$, accounted for $7.10 \%$ of eigen value. Its presence in the stream sediments may have been as a result of similar sources of elemental enrichment like leachate from rusty iron materials and lateritic soil. This element though constitutes the highest concentration among other elements, its abundance nevertheless may be harmful to biologic materials in the environment.

Factor analyses for floodplain soils showed four groups of elemental association; the first group, $\mathrm{Cu}, \mathrm{Ni}, \mathrm{Co}, \mathrm{Mn}, \mathrm{As}$, $\mathrm{Sr}, \mathrm{V}$ and $\mathrm{Cr}$ accounted for $41.51 \%$ of total variance of eigen 
Table 6 Principal component analyses of PHE in stream sediments

\begin{tabular}{lrrrl}
\hline & \multicolumn{3}{l}{ 1 } & \multicolumn{2}{l}{3} \\
\hline $\mathrm{Cu}$ & $\mathbf{0 . 9 2 7}$ & 0.043 & 0.208 & -0.016 \\
$\mathrm{~Pb}$ & $\mathbf{0 . 7 4 5}$ & -0.391 & -0.103 & 0.234 \\
$\mathrm{Zn}$ & $\mathbf{0 . 9 4 0}$ & -0.203 & -0.014 & 0.08 \\
$\mathrm{Ni}$ & 0.338 & $\mathbf{0 . 7 4 1}$ & 0.055 & -0.393 \\
$\mathrm{Co}$ & -0.296 & $\mathbf{0 . 8 4 4}$ & -0.185 & -0.04 \\
$\mathrm{Mn}$ & -0.242 & 0.42 & -0.498 & $\mathbf{0 . 6 0 4}$ \\
$\mathrm{As}$ & $\mathbf{0 . 5 8 1}$ & 0.307 & 0.322 & 0.466 \\
$\mathrm{Th}$ & -0.531 & -0.342 & $\mathbf{0 . 6 2 9}$ & 0.193 \\
$\mathrm{Sr}$ & $\mathbf{0 . 8 7 5}$ & -0.17 & -0.045 & -0.084 \\
$\mathrm{Cd}$ & $\mathbf{0 . 8 2 1}$ & -0.084 & 0.015 & -0.202 \\
$\mathrm{~V}$ & 0.123 & $\mathbf{0 . 7}$ & 0.415 & -0.006 \\
La & -0.763 & -0.034 & $\mathbf{0 . 4 8 3}$ & 0.045 \\
Cr & $\mathbf{0 . 7 2}$ & 0.4 & 0.271 & 0.192 \\
Total & 5.735 & 2.53 & 1.32 & 0.923 \\
\% of Variance & 44.117 & 19.465 & 10.154 & 7.101 \\
Cumulative \% & 44.117 & 63.582 & 73.736 & 80.837 \\
\hline
\end{tabular}

Table 7 Principal component analyses of PHE in both topsoil and subsoils of floodplains

\begin{tabular}{lrrrr}
\hline & \multicolumn{3}{c}{2} & \multicolumn{2}{l}{3} \\
\hline $\mathrm{Cu}$ & $\mathbf{0 . 8 5 2}$ & 0.444 & 0.008 & 0.176 \\
$\mathrm{~Pb}$ & 0.315 & $\mathbf{0 . 8 7 8}$ & 0.028 & -0.057 \\
$\mathrm{Zn}$ & 0.218 & $\mathbf{0 . 9 2 6}$ & 0.248 & 0.111 \\
$\mathrm{Ni}$ & $\mathbf{0 . 9 6 2}$ & 0.055 & 0.166 & 0.030 \\
$\mathrm{Co}$ & $\mathbf{0 . 6 3 8}$ & -0.581 & 0.369 & -0.044 \\
$\mathrm{Mn}$ & $\mathbf{0 . 5 5 2}$ & -0.307 & $\mathbf{0 . 5 1 4}$ & -0.314 \\
$\mathrm{As}$ & $\mathbf{0 . 6 4 0}$ & 0.073 & -0.593 & 0.182 \\
$\mathrm{Th}$ & $\mathbf{0 . 6 7 4}$ & -0.093 & -0.008 & -0.565 \\
$\mathrm{Sr}$ & $\mathbf{0 . 7 9 1}$ & $\mathbf{0 . 4 0 7}$ & -0.131 & -0.14 \\
$\mathrm{Cd}$ & -0.071 & $\mathbf{0 . 8 1 6}$ & $\mathbf{0 . 4 3}$ & 0.164 \\
$\mathrm{~V}$ & $\mathbf{0 . 6 8 1}$ & -0.581 & -0.175 & 0.302 \\
La & 0.328 & -0.504 & $\mathbf{0 . 5 3 7}$ & $\mathbf{0 . 4 3 2}$ \\
Cr & $\mathbf{0 . 9 0 4}$ & -0.062 & -0.315 & 0.061 \\
Total & 5.396 & 3.703 & 1.461 & 0.829 \\
\% of variance & 41.51 & 28.482 & 11.236 & 6.375 \\
Cumulative \% & 41.51 & 69.992 & 81.228 & 87.603 \\
\hline
\end{tabular}

value. Like for the stream sediments, these elements may have been enriched by urban activities such as domestic waste lechates, automobile waste and the use of pesticides because the floodplain is a repository for all kinds of mismanage waste disposal in the urban areas. The second group of elements, $\mathrm{Pb}, \mathrm{Zn}$ and $\mathrm{Cd}$, accounted for $28.48 \%$ of eigen value. These elements may have been enriched in the floodplain soils by automobile washout, domestic and industrial waste. The third group includes $\mathrm{Mn}$ and La. These elements accounted for $11.24 \%$ of eigen value in the factor analyses. It can be said these elements may have enriched by the underlining rock that is granitic in origin. The fourth group, which is just La, accounted for $6.38 \%$ of eigen value. This element may have been enriched by weathered basement rocks that underline the study area.

Comparison of the mean concentration of potentially harmful elements in floodplain soils, stream sediments with other referenced studied works, within Nigeria and outside the world, was done in order to ascertain the level of enrichment of these elements with these areas, Table 8. The results showed that for $\mathrm{Cu}$, there were considerably higher concentration (ppm) in the floodplain subsoil (FPT2) relative to the floodplain topsoil (FPT1) and stream sediments (SS) but were higher than the average shale concentration [55]. Similarly, the mean concentration of $\mathrm{Cu}$ (ppm) in this study area (FPT1, FPT2 and SS) was found to be higher than the mean concentration for almost all the referenced studied works but lower than Alapere wetland [35], Apomu Ikire stream sediments [36] and Ikorodu streams, [32]. The mean Pb concentration (ppm) for floodplain topsoil (93.5) was found to be higher than floodplain subsoil (77.9), as well as for stream sediments (67.3), but were generally higher than the mean concentration of $\mathrm{Pb}$ in Apomu lkire [36], Akure floodplain topsoil [6], Akure floodplain subsoil [6], Lagos lagoon [33], Average Shale Concentration [55], Tupilipalem Coast Sediment, India, [20] and Ikorodu streams, Lagos [32] with a mean $\mathrm{Pb}$ (ppm) concentration of 65.52, 58.95, 56.33, 20.27, $20.00,5.67$ and 9.73 , respectively, but were slightly lower than the mean concentration of $\mathrm{Pb}$ in Ondo Stream sediments [7], Ndemilli river [8] and Xiangjiang River, Hunan Province, [41]. This suggests that $\mathrm{Pb}$ in this present study area is significantly enriched to a status that may pose environmental health risk. This is particularly so because of the high priority toxicity of lead to the biota. Results for the other elements in the study area were found to be considerably higher in this study than the results of the average shale concentration except for $\mathrm{Ni}$, Th, $\mathrm{Sr}$ and $\mathrm{La}$. In some instances, the average concentrations of these elements in this present study area were found to be two- to fourfold higher than the average shale value as seen in As, $\mathrm{Cd}, \mathrm{Zn}$ and $\mathrm{Pb}$, Table 8 . Similarly comparing the results of this study with the other elements in other referenced areas, it was observed that there is significant enrichment of PHEs more than some the referenced areas. The implication of this is that the stream sediments and floodplain soil under investigation have received significant enrichment of PHEs.

The I-geo index result for higher-priority PHEs ( $\mathrm{Pb}$, $\mathrm{Zn}, \mathrm{Mn}, \mathrm{As}, \mathrm{Cd}$ and $\mathrm{Cr}$ ) in the floodplain soils and stream sediments are presented in Fig. 6 . Pb ranges from unpolluted to strongly polluted, with over $50 \%$ of the samples falling on strongly polluted status. $\mathrm{Pb}$ also ranges from 
Table 8 Comparison of floodplain soils and stream sediments of the study area with other study areas

\begin{tabular}{llllllllllllllll}
\hline & FPT1 Mean & FPT2 Mean & SS Mean & (A) & (B) & (C) & (D) & (E) & (F) & (G) & (H) & (i) & (J) & (K) \\
\hline $\mathrm{Cu}$ & 71.1 & 76.6 & 70.3 & 78.14 & 36.5 & 27.43 & 21.24 & 36.04 & 50 & 213 & 64.4 & 38.29 & 3.55 & 9.99 \\
$\mathrm{~Pb}$ & 93.5 & 77.9 & 67.3 & 65.52 & 78.7 & 58.95 & 56.33 & 20.27 & 20 & 557 & 106.9 & 96.84 & 5.67 & 9.73 \\
$\mathrm{Zn}$ & 826 & 622.3 & 357.8 & 429.95 & 490 & 223.1 & 149.1 & 72.33 & 90 & 1863 & 482.2 & 227.2 & 14.2 & 95.21 \\
$\mathrm{Ni}$ & 25.3 & 27.2 & 24.9 & - & 8.9 & 14.86 & 13.76 & 12.66 & 80 & 49 & 18.73 & 29.48 & 6.43 & 3.30 \\
$\mathrm{Co}$ & 24.6 & 28.7 & 29.3 & - & 5.4 & 24.29 & 23.96 & 9.52 & 20 & - & 7.19 & 15.76 & - & 2.93 \\
$\mathrm{Mn}$ & 1323 & 1190 & 2138 & 1831.2 & 520 & 983.3 & 806.4 & 495 & 850 & - & 282.2 & 1300 & 54.8 & 126.1 \\
$\mathrm{As}$ & 3.1 & 3.4 & 3.3 & - & - & - & - & 2.99 & 1.8 & - & 5.02 & - & - & 0.99 \\
$\mathrm{Th}$ & 4.3 & 4.5 & 5.9 & - & 10.2 & 14.43 & 17.48 & 3.29 & 12 & - & - & 19.34 & - \\
$\mathrm{Sr}$ & 32.9 & 30.6 & 53.4 & - & 43.6 & - & - & 31.43 & 400 & - & - & - & - & 11.94 \\
$\mathrm{Cd}$ & 1.42 & 1.28 & 0.7 & 0.43 & 0.7 & - & - & 0.27 & 0.3 & - & 0.57 & 5.89 & 0.71 & 0.18 \\
$\mathrm{~V}$ & 142.6 & 165.5 & 161.7 & - & 59.2 & 73.05 & 68.71 & 33.64 & 130 & 41 & - & 83.18 & - \\
$\mathrm{La}$ & 32.2 & 34 & 31.6 & - & 30.1 & 56.76 & 61 & 26.97 & 40 & - & - & 45.24 & - \\
$\mathrm{Cr}$ & 108.8 & 128.5 & 132.8 & 83.75 & 36.6 & 40.43 & 35.38 & 31.52 & 100 & 61 & 54.62 & 73.26 & 9.25 & 12.53 \\
\hline
\end{tabular}

(A), Apomu lkire [36]; (B), Ondo Stream sediments [7]; (C), Akure floodplain topsoil [6]; (D), Akure floodplain subsoil [6]; (E), Lagos lagoon [33]; (F), Average Shale Concentration [55]; (G), Alapere wetland [35]; (H), Ndemilli river [8]; (I), Xiangjiang River, Hunan Province, [41]; (J), Tupilipalem Coast Sediment, India, [20]; (K), Ikorodu streams, Lagos [32]; FPT1 Mean, floodplain topsoil (This study); FPT2 mean, floodplain subsoil (This study); SS, Stream sediment (This study)

Fig. 6 Geo accumulation index box plot of selected potentially harmful elements in the geo-media (floodplain soils and Stream Sediments) of the study area

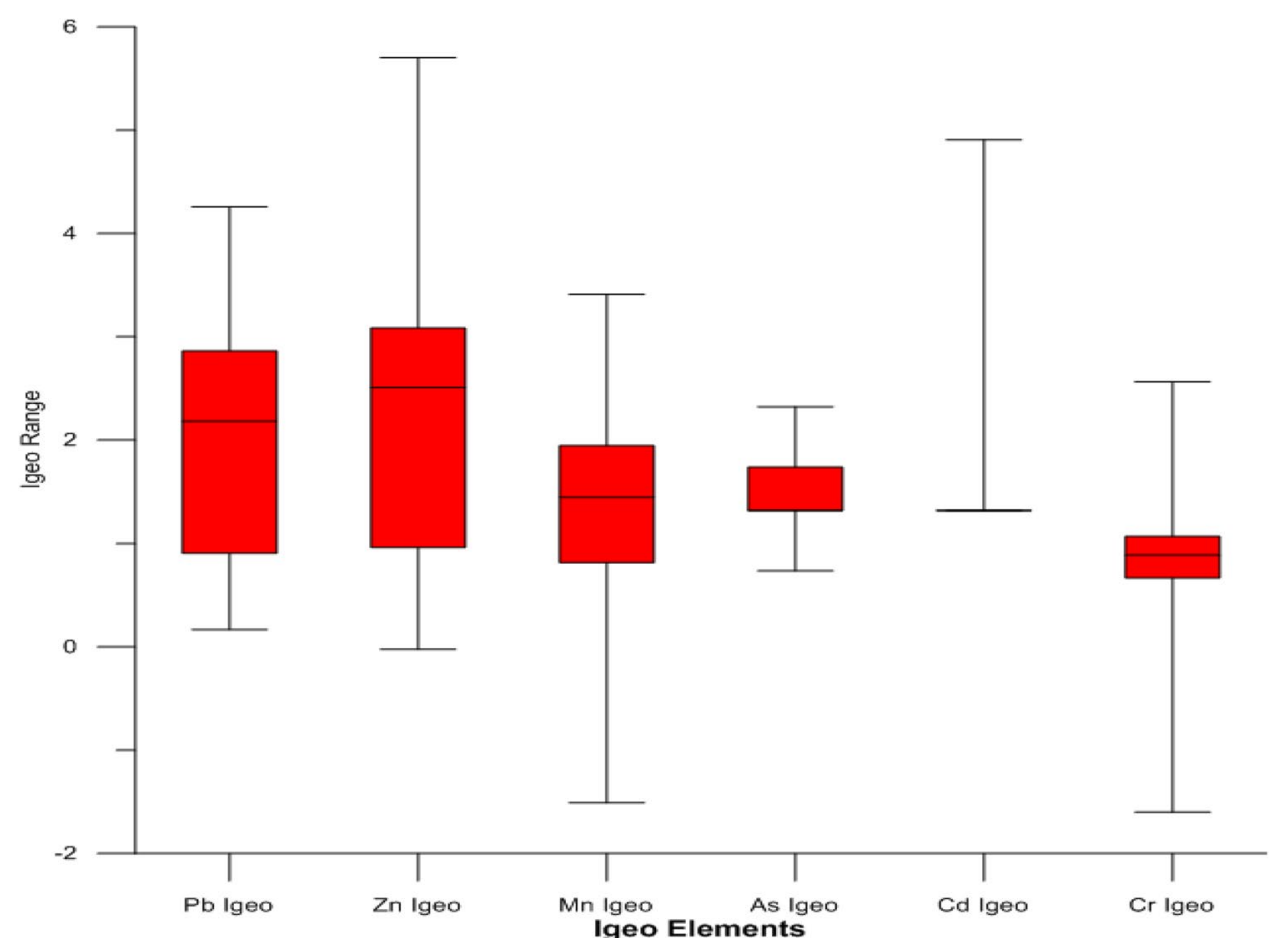

Similarly, selected PHEs (Pb, Zn, Mn, As, Cd and Cr) were further subjected to metal ratio index assessment and the result is presented in Fig. 7. From the results, it was found that some locations exhibits metal ratio $<1.0$ as seen in Fig. 7, which suggest that such locations have reached relatively high pollution status that call for environmental concern, activities such as automobile washout, indiscriminate waste disposal (domestic and industrial), hospital waste disposal among others. 
Fig. 7 Metal ratio index box plot of selected potentially harmful elements in the geo-media (floodplain soils and Stream Sediments) of the study area

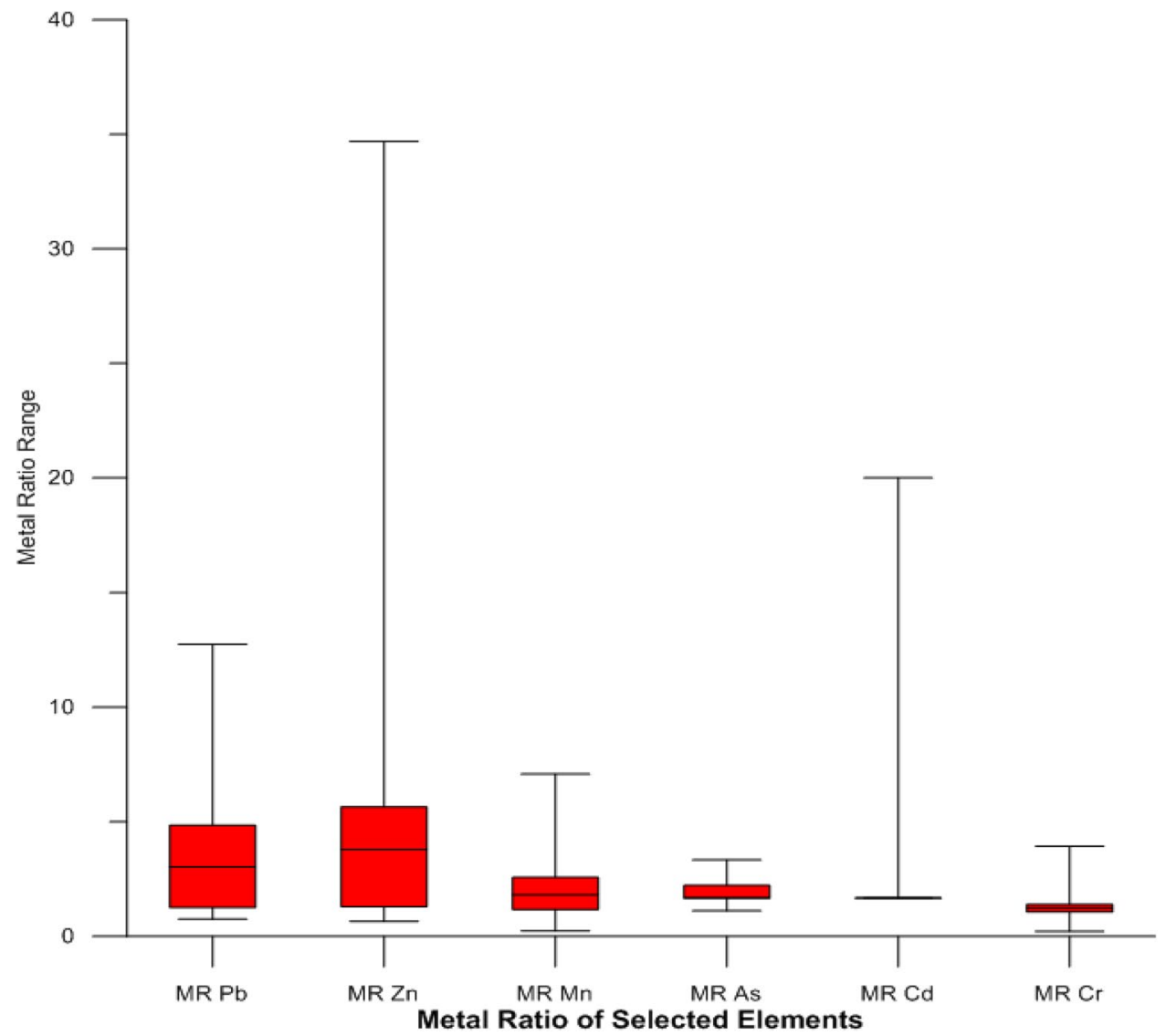

\section{Conclusion}

Sixty (60) samples of floodplain soils (topsoil and subsoil) and stream sediments in Ile-Ife and environs were analysed for total elemental concentration to know the enrichment status, distribution pattern and potential environmental hazard. There results showed that there is a considerable level of PHEs in the samples analysed in the study area, with a decreasing trend of average contents of PHEs studied showing that $\mathrm{Mn}>\mathrm{Zn}>\mathrm{V}>\mathrm{Cr}>\mathrm{Pb}>\mathrm{La}>\mathrm{Sr}>$ $\mathrm{Cu}>\mathrm{Ni}>\mathrm{Co}>\mathrm{Th}>\mathrm{As}>\mathrm{Cd}$.

The average metal content of $\mathrm{Cu}$ in subsoil (76.5) was found to be slightly higher than topsoil (71.1) and stream sediments (70.3), suggesting similar level of Cu enrichment in the study area. This was also observed in $\mathrm{Ni}, \mathrm{Co}$ and $\mathrm{As}$ among other elements in the geo-media. Their mean concentrations are of close range of enrichment. However, the mean concentration of $\mathrm{Pb}, \mathrm{Zn}$ and $\mathrm{Cd}$ are significantly at variance among topsoil, subsoil and stream sediment. $\mathrm{Cd}$ in topsoil and subsoil are 4 folds higher than the stream sediments, suggesting significant level of enrichment in the topsoil and subsoil in the study area relative to the stream sediments. This suggests that the floodplain soil has received significant load of $\mathrm{Cd}$, a high-priority toxic element in the floodplain soil. The implication of this is that the floodplain is a repository for the enrichment of PHEs in the urban environment, which should be of great concern, because $\mathrm{Cd}$ is a high priority trace element of the PHEs in the environment.

Spatial distribution map revealed elevated concentration of PHEs in the study area were largely influenced by urban activities. Comparing the results of the floodplain soils and stream sediments with average shale concentration (ASC), it showed that $\mathrm{Cu}, \mathrm{Pb}, \mathrm{Zn}, \mathrm{Co}, \mathrm{Mn}, \mathrm{As}, \mathrm{Cd}, \mathrm{V}$ and $\mathrm{Cr}$ were found to be higher than ASC. This suggests that these PHEs may have reached considerable enrichment level that can pose environmental health risk to the ecosystem, such as the soil for agricultural activities, water bodies such as the rivers, the dam that is very essential for use by the inhabitant/ residence of the OAU campus and in some instances atmospheric particulates that come from loosed soil particles in the urban area. However $\mathrm{Ni}$, Th, Sr and La are found to be lower than the average shale concentrations which suggest that these other PHEs are relatively not at a risk level of enrichment in the environmental media.

Results of pollution indexes such as geoaccumulation and metal ratio revealed that high-priority PHEs which include $\mathrm{Pb}, \mathrm{Zn}, \mathrm{Mn}, \mathrm{As}, \mathrm{Cd}$ and $\mathrm{Cr}$ have reached significant pollution status in the floodplain soils and stream 
sediments in Ile-Ife area which calls for concern. These elements assessments range from slightly polluted in some locations to strongly polluted as observed in the quantification assessment with Igeo index. Similar result was found for metal ratio evaluation, where $\mathrm{Pb}, \mathrm{Zn}, \mathrm{Mn}, \mathrm{As}, \mathrm{Cd}$ and $\mathrm{Cr}$ are $>1$ in the results.

The enrichment of PHEs in the floodplain soils and stream sediments may have been caused by external factors such as indiscriminate refuse disposal, industrial waste mismanagement and agricultural runoff that possibly contain herbicides, inorganic fertilizer and generally anthropogenic inputs. Based on this study, it is important for relevant environmental agencies and regulators to monitor effectively and regulate the input of anthropogenic sources of PHEs enrichment in the floodplain soils and stream sediments so as to reduce anthropogenic input in these geo-media. In the same vein, effort should be made to carry out further works on lead $(\mathrm{Pb})$ isotope analysis as well as sequential analyses of the PHEs in this study area in other to track accurately the main source(s) of $\mathrm{Pb}$ and associated elements and ascertain the potential bioavailability/ mobility of these PHEs in the biota such as plant and animals in the study area

Acknowledgements The authors sincerely appreciate the efforts of David, Bada and Eric. Their contribution to the success of this research data acquisition is highly appreciated. Similarly, the authors are grateful to all the anonymous reviewers for their meticulous work in the improvement of this article.

\section{Compliance with ethical standards}

Conflict of interest The authors hereby state that there is no conflict of interest in this article.

\section{References}

1. Abuloye AP, Nevo AO, Eludoyin OM, Popoola KS, Awotoye OO (2017) An assessment of effective temperature, relative strain index and dew point temperature over Southwest Nigeria. J Climatol Weather Focast 5:1. https://doi.org/10.4172/23322594.1000192

2. Adedeji OH, Olayinka OO, Tope-Ajayi OO (2019) Spatial distribution and health risk assessment of soil pollution by heavy metals in ljebu-Ode. Nigeria. J Health Pollut 9(22):190601

3. Aleksander-Kwaterczak U, Plenzler D (2019) Contamination of small urban watercourses on the example of a stream in Krakow (Poland). Environ Earth Sci 78:530. https://doi.org/10.1007/ s12665-019-8509-4

4. Alibrahim ZO, Williams CD (2016) Assessment of bioavailability of some potential toxic metals in mining-affected soils using EDTA extraction and principle component analysis (PCA) approach, Derbyshire UK. Interdiscip J Chem 1(2):58-65. https ://doi.org/10.15761/IJC.1000110

5. Alloway BJ (1995) The origin of heavy metals in soils. In: Alloway BJ (ed) Heavy metals in soils. Blackie Academic and Professional, London, pp 38-57
6. Asowata IT, Omokolade OG (2019) Trace elements characterisation in floodplain soils underlain by crystalline rocks, Akure Southwestern Nigeria. Int J Adv Gesosci 7(1):31-46

7. Asowata IT, Abimbola AF, Komolafe BA, Adepeko LH (2014) Geochemical assessment of influence of urbanization on heavy metal enrichment in stream sediments of Ondo Town, Southwestern Nigeria. Global J Pure Appl Sci 20(2014):95-103. https://doi.org/10.4314/gjpas.v20i2.3

8. Asowata TI, Olatunji AS (2018) Enrichment of trace elements in urban soils and sediments in a typical sedimentary environment; Onitsha metropolis southeastern Nigeria. J Environ Geol 2(2):47-60

9. Awomeso JA, Taiwo AM, Dada EO, Ayantobo OO (2017) Human health and environmental assessments of small-scale and artisanal mining activities in the Gold City of ljeshaland, Southwestern Nigeria. Environ Syst Res 6:18. https://doi. org/10.1186/s40068-017-0095-4

10. Babcsányi I, Tamás M, Szatmári J, Hambek-Oláh B, Farsang A (2020) Assessing the impacts of the main river and anthropogenic use on the degree of metal contamination of oxbow lake sediments (Tisza River Valley, Hungary). Journal of Soils and Sediments 20:1662-1675. https://doi.org/10.1007/s1136 8-019-02516-y

11. Caby R (2003) Terrane assembly and geodynamic evolution of Central-Western Hoggar: a synthesis. J Afr Earth Sci 37:133-159

12. Caby R, Boesse JM (2001) Pan-African nappe system in southwest Nigeria: the Ife-Ilesha schist belt. J Afr Earth Sc 33:211-225

13. Ciszewski D, Grygar TM (2016) A review of flood-related storage and remobilization of heavy metal pollutants in river systems. Water Air Soil Pollut 227:239. https://doi.org/10.1007/s1127 0-016-2934-8

14. Ebong GA, Etuk HS, Dan EU (2018) Distribution, pollution index and associated health risk of trace metals in waste-impacted soils within Akwa Ibom State, Nigeria. Geosyst Eng 21(3):121134. https://doi.org/10.1080/12269328.2017.1376291

15. El-Radaideh N, Al-Taani AA (2018) Geo-environmental study of heavy metals of the agricultural highway soils. NW J Arab J Geosci 11:787. https://doi.org/10.1007/s12517-018-4099-9

16. El-Radaideh N, Al-Taani AA, Al Khateeb W (2017) Characteristics and quality of reservoir sediments, Mujib Dam, Central Jordan as a case study. Environ Monit Assessment. https://doi. org/10.1007/s10661-017-5836-3

17. Federal Survey Nigeria, 1964 . Sheet 263 , map publication.

18. Foulds SA, Brewer PA, Macklin MG, Haresign W, Betson RE, Rassner SM (2014) Flood-related contamination in catchments affected by historical metal mining: an unexpected and emerging hazard of climate change. Sci Total Environ 476-477:165-180

19. Froger $C$, Ayrault $S$, Evrard $O$, Monvoisin G, Bordier L, Lefèvre I, Quantin C (2018) 2018 Tracing the sources of suspended sediment and particle-bound trace metal elements in an urban catchment coupling elemental and isotopic geochemistry, and fallout radionuclides. Environ Sci Pollut Res 25:28667-28681. https://doi.org/10.1007/s11356-018-2892-3

20. Ganugapenta S, Nadimikeri J, Chinnapolla SRRB, Ballari L, Madiga R, Nirmala K, Prasad TL (2018) Assessment of heavy metal pollution from the sediment of Tupilipalem Coast, southeast coast of India. Int J Sedim Res. https://doi.org/10.1016/j.ijsrc .2018.02.004i

21. He M, Zhenh H, Peter D, Clift PD, Ryuji Tada RT, Wu W, Luo C (2015) Geochemistry of fine-grained sediments in the Yangtze River and the implications for provenance and chemical weathering in East Asia. Progress Earth Planetary Sci 2:32. https://doi. org/10.1186/s40645-015-0061-6

22. Jayaraju N, Sundara Raja Reddy BC, Reddy KR (2011) Anthropogenicmetal pollution in surface sediments of the Tambaraparni 
River Estuary. Chem Ecol. https://doi.org/10.1080/02757 540.2011.570752

23. Kiss T, Sándor A (2009) Land-use changes and their effect on floodplain aggradation along the Middle-Tisza River. Hungary Acta Geogr Debrecina Landsc Environ 3:1-10

24. Lebreton-Anberree J, Li S, Li SF, Spicer RA, Zhang ST, Su T, Deng C, Zhou ZK (2016) Lake geochemistry reveals marked environmental change in Southwest China during the Mid Miocene Climatic Optimum. Sci Bull. https://doi.org/10.1007/s1143 4-016-1095-x

25. Lyons WB, Harmon RS (2012) Why urban geochemistry? Elements: an international magazine of mineralogy. Geochem Petrol. https://doi.org/10.2013/gelements.8.6.417

26. Machowski R, Rzetala MA, Rzetala M, Solarski M (2019) Anthropogenic enrichment of the chemical composition of bottom sediments of water bodies in the neighborhood of a non-ferrous metal smelter (Silesian Upland, Southern Poland) Scientific Report. Nat Res 9:14445. https://doi.org/10.1038/s41598-01951027-W

27. Mimba ME, Ohba T, Fils SCN, Nforba MT, Numanami N, Bafon TG, Aka FT, Suh CC (2018) Regional geochemical baseline concentration of potentially toxic trace metals in the mineralized Lom Basin, East Cameroon: a tool for contamination assessment. Geochem Trans 19:11. https://doi.org/10.1186/s1293 2-018-0056-5

28. Muller G (1979) Schwermetalle in den sedimenten des RheinsVeranderungen seit 1971. Umschau 79(24):778-783

29. Naser HA (2013) Assessment and management of heavy metal pollution in the marine environment of the Arabian Gulf: a review. Mar Pollut Bull 72:6-13

30. Nigeria Geological Survey Agency (NGSA) (2006) Published by the Authority of the Federal Republic of Nigeria.

31. Odewande AO, Abimbola AF (2008) Concentration indices and heavy metal concentrations in Urban soil of Ibadan metropolis. Southwestern Nigeria Environ Geochem Health 30:243-254

32. Odukoya AM, Akande O (2015) Metal contamination assessment in the urban stream sediments and tributaries of coastal area southwest Nigeria. Chin J Geochem 34:431-446. https://doi. org/10.1007/s11631-014-0027-1

33. Olatunji AS, Abimbola AF (2010) Geochemical Evaluation of the Lagos Lagoon sediments and water. World Appl Sci J 9(2):178-193

34. Olatunji AS, Abimbola AF, Afolabi OO (2009) Geochemical assessment of industrial activities on the quality of sediments and soils within the LSPDC industrial estate Odogunyan, Lagos Nigeria. Global J Environ Res 3(3):252-7

35. Olatunji AS, Ajayi A (2016) Potentially toxic contamination of cultivated wetlands in Lagos, Nigeria. J Health Pollut 6:95-102

36. Olatunji OS, Kolawole T, Afolabi OO, Nwoko CE (2016) Trace metals evaluation of stream sediments in suburban environment: a case study of Apomu-Ikire Southwestern Nigeria. J Min Geol 52(1):67-74

37. Omogbai BE (2010) Rain days and their predictability in southwestern region of Nigeria. J Hum Ecol 31:185-195

38. Oyebamiji A, Odebunmi A, Ruizhong H, Rasool A (2018) Assessment of trace metals contamination in stream sediments and soils in Abuja leather mining, southwestern Nigeria. Acta Geochim 37(4):592-613. https://doi.org/10.1007/s11631-017-0256-1

39. Ozkan EY, Buyukisik B (2012) Geochemical and statistical approach for assessing heavy metal accumulation in the southern Black Sea sediments. Ekoloji 21(83):11-24

40. Pande N, Nayak GN (2013) Understanding distribution and abundance of metals with space and time in estuarine mud flat sedimentary environment. Environ Earth Sci 70:2561-2575
41. Peng $B$, Xiaoya $T$, Changxun $Y$, Changyin $T$, Chunyan $Y$, Guang Y, Qian Kesu Y, Xianglin T (2011) Geochemistry of trace metals and $\mathrm{Pb}$ isotopes of sediments from the lowermost Xiangjiang River, Hunan Province (P R China): implications on sources of trace metals. Environ Earth Sci 64:1455-1473. https://doi. org/10.1007/s12665-011-0969-0

42. Mikoshiba UM, Ima N, Terashima S, Tachibana Y, Okay T (2006) Geochemical mapping in Northern Ilonshu, Japan. Appl Geochem 21:492-514

43. Muller G (1969) Index of geo-accumulation in sediments of the Rhine River. Geol J 2(3):108-118

44. Rahaman MA (1989) Review of the basement geology of Southwestern Nigeria. In: Kogbe CA (ed) Geology of Nigeria. Elizabethan Publishing Co., Lagos, pp 39-56

45. Rastmanesh F, Safaie S, Zarasvandi AR, Edraki M (2018) Heavy metal enrichment and ecological risk assessment of surface sediments in Khorramabad River West Iran. Environ Monit Assess 190:273. https://doi.org/10.1007/s10661-018-6650-2

46. Sierra $C$, Ruíz-Barzola $O$, Menéndez $M$, Demey JR, Vicente-Villardón JL (2017) Geochemical interactions study in surface river sediments at an artisanal mining area by means of Canonical (MANOVA)-Biplot. J Geochem Explor 175:72-81

47. Singh $P$ (2009) Major, trace and REE geochemistry of the Ganga River sediments: influence of provenance and sedimentary processes. Chem Geol 266:251-264

48. Singh P (2010) Geochemistry and provenance of stream sediments of the Ganga River and its major tributaries in the Himalayan region, India. Chem Geol 269:220-236

49. Singh H, Pandey R, Kumar S, Singh D, Shukla N (2017) Assessment of heavy metal contamination in the sediment of the River Ghaghara, a major tributary of the River Ganga in Northern India. Appl Water Sci 7:4133-4149. https://doi.org/10.1007/ s13201-017-0572-y

50. Singh H, Singh D, Singh SK, Shukla DN (2017) Assessment of river water quality and ecological diversity through multivariate statistical techniques, and earth observation dataset of rivers Ghaghara and Gandak India. Int J River Basin Manag. https:// doi.org/10.1080/15715124.2017.1300159

51. Singer DM, Jefferson AJ, Eric L, Traub EL, Perdrial N (2018) Mineralogical and geochemical variation in stream sediments impacted by acid mine drainage is related to hydro-geomorphic setting. Elem Sci Anth 6:31. https://doi.org/10.1525/eleme nta.286

52. Turekian KK, Wedephol KH (1961) Distribution of the elements in some major units of the earth's crust. Bull Geol Soc Am $72: 175-192$

53. Varol M (2011) Assessment of heavymetal contamination in sediments of the Tigris River (Turkey) using pollution indices and multivariate statistical tech niques. J Hazard Mater 195:355-364

54. Walsh CJ, Roy AH, Feminella JW, Contigham PD, Groffman PM, Morgan RP (2005) The urban stream syndrome: current knowledge and the search for the cure. J N. Am. Benhological Soc 24:706-723

55. Wedepohl KH (1978) This book gives basic data on the distribution of all chemical elements in the lithosphere, hydrosphere and atmosphere. Handbook of Geochemistry I.II-I.I5. Springer, Berlin

Publisher's Note Springer Nature remains neutral with regard to jurisdictional claims in published maps and institutional affiliations. 